\title{
Pedagógusok innovatív munkahelyi viselkedése mint a folyamatos szakmai fejlődés egyik forrása
}

\section{Fazekas Ágnes, Horváth László ${ }^{2}$}

\author{
${ }^{1}$ ELTE Eötvös Loránd Tudományegyetem \\ Felnőttképzés-kutatási és Tudásmenedzsment Intézet egyetemi adjunktusa \\ e-mail: fazekas.agnes@ppk.elte.hu \\ ${ }^{2}$ ELTE Eötvös Loránd Tudományegyetem, Neveléstudományi Intézet \\ egyetemi adjunktusa \\ e-mail: horvath.laszlo@ppk.elte.hu \\ ORCID: https://orcid.org/0000-0003-0003-1045
}

\begin{abstract}
Jelen tanulmány célja a hazai oktatási innovációkat vizsgáló kutatás másodelemzéséböl levonható releváns következtetések megállapitása a pedagógusok szakmai fejlődésének szempontjából. A másodelemzés tudásháttereként a pedagógusok munkahelyi tanulásának elméleti megközelítését választottuk, amely összeköti a pedagógusok innovatív munkahelyi viselkedését és a tanárok tanulásának témáját. A másodelemzés alapján megállapítható, hogy az újítások keletkezésének és terjedésének fontos forrása a kutatási eredmények alapján más kollégák vagy intézmények inspiráló gyakorlata, a különböző szakmai hálózatokban való részvétel, illetve a konkrét munkahelyi/szakmai probléma megoldásának igénye. Ezzel összefüggésben a kutatás megerősítette a munkatársak újításokra való nyitottságának mint olyan attitüdnek a fontosságát, amely hozzájárul a helyi szintü újítások keletkezéséhez, terjedéséhez és az ezen folyamatokhoz kapcsolódó tanuláshoz.
\end{abstract}

Kulcsszavak: folyamatos szakmai fejlődés, innováció, innovatív munkahelyi viselkedés, Innova

DOI: 10.37205/TEL-hun.2019.3-4.03

\section{Bevezetés}

Jelen tanulmány az ELTE PPK Neveléstudományi Intézetében zajló, a pedagógusok szakmai fejlődését vizsgáló „Models of Teacher Learning” (MoTeL) ${ }^{1}$ című kutatás keretein belül készült. Célja a hazai oktatási innovációkat vizsgáló Innova²

\footnotetext{
${ }^{1}$ „A pedagógusok folyamatos szakmai fejlődési modelljeinek vizsgálata a köznevelési rendszer, a szervezet és az egyén szintjén" (MoTeL) címü, 128738 számú projekt a Nemzeti Kutatási Fejlesztési és Innovációs Alapból biztosított támogatással, a K_18 pályázati program finanszírozásában valósult meg.

${ }^{2}$ „A helyi innovációk keletkezése, terjedése és rendszerformáló hatása az oktatási ágazatban - Innova” címü kutatás, OTKA azonosító: 115857
} 
kutatás másodelemzéséből kirajzolódó releváns következtetések bemutatása. A másodelemzés alapját adó kutatás kiválasztása során fontos szempont volt, hogy olyan, a pedagógusok folyamatos szakmai fejlődését fókuszba helyező adatok feldolgozása történjen meg, ahol rendelkezésünkre állnak az eredeti adatbázisok, illetve birtokunkban vannak a vizsgálati eszközök is.

$\mathrm{Az}$ itt bemutatott elemzési munkán túl további három kutatást ${ }^{3}$ is bevontunk a másodelemzésbe. Ezek eredményei itt terjedelmi korlátok miatt nem jelennek meg, ezek egy bővebb kéziratban érhetőek el (Fazekas - Horváth, 2019).

$\mathrm{Az}$ alábbiakban elsőként röviden felvázoljuk a vizsgálódásunk alapját adó elméleti hátteret, majd ismertetjük a másodelemzésbe bevont kutatás és a hozzá kapcsolódó adatbázisok sajátosságait. Ezt követően bemutatjuk a feltárt eredményeket, és végül, a tanulmány zárásaként, összegezzük ezek főbb megállapításait.

\section{A másodelemzés elméleti háttere}

$\mathrm{Az}$ adatbázisok másodelemzésének tudásháttereként a pedagógusok munkahelyi tanulásának elméleti megközelítését választottuk, tekintettel arra, hogy a pedagógusok tanulása tekinthető talán a legerősebb olyan közös kiindulási pontnak, amely összeköti a MoTeL kutatást a másodelemzésekbe bevont kutatással.

A kapcsolódó irodalmakban - beleértve többek között neveléstudományi, a kurrikulum-elméleti, kurrikulum-fejlesztési, és az implementációkutatásokhoz kapcsolódó írásokat - számos olyan megközelítéssel, elmélettel, modellel találkozhatunk, amelyek a pedagógusok munkahelyi tanulásával foglalkoznak (lásd például Darling-Hammond, 1990; Cohen - Hill, 2001; Boekaerts, 2010). Bár e modellek nem felelnek meg egymásnak teljesen, közös pontjuk, hogy jellemzően a tanulás konstruktivista megközelítésére épülnek. A tanári tanulás megközelítések sajátosságát egyfelől az adja, hogy elsődleges tanulási környezetként az iskola mint munkahely jelenik meg bennük, illetve a tacit és a gyakorlat során kialakuló és érvényesülő tudás azonosítható leginkább valós eredményként. Az Innova kutatás elődjeként értelmezhető ImpAla projektben alkalmazott elméleti megközelítés (lásd Fazekas, 2018) a pedagógusok tanulásának megragadása során elsősorban arra a modellre támaszkodott, amelyet Jan D. Vermunt és szerzőtársa Maaike

\footnotetext{
${ }^{3} 1$. Pedagógus-együttmúködésen alapuló tanulás és szervezeti kontextus kapcsolatát vizsgáló, az Oktatáskutató és Fejlesztő Intézetben megvalósult kutatás. 2. Az ELTE PPK-n zajlott és a kurrikulum megváltoztatására irányuló uniós finanszírozású fejlesztések hatásmechanizmusait feltáró kutatás. 3. A SZTE Közoktatás- és Vezetőképző Intézetében megvalósult, a szervezeti müködés a pedagógusok szakmai kompetenciáira gyakorolt hatásának feltárására irányuló kutatás.
} 
D. Endedijk alkotott meg (2011). Jelen tanulmányban követjük ezt, és mi magunk is e modellt tekintjük meghatározó kiindulópontunknak (1. ábra).

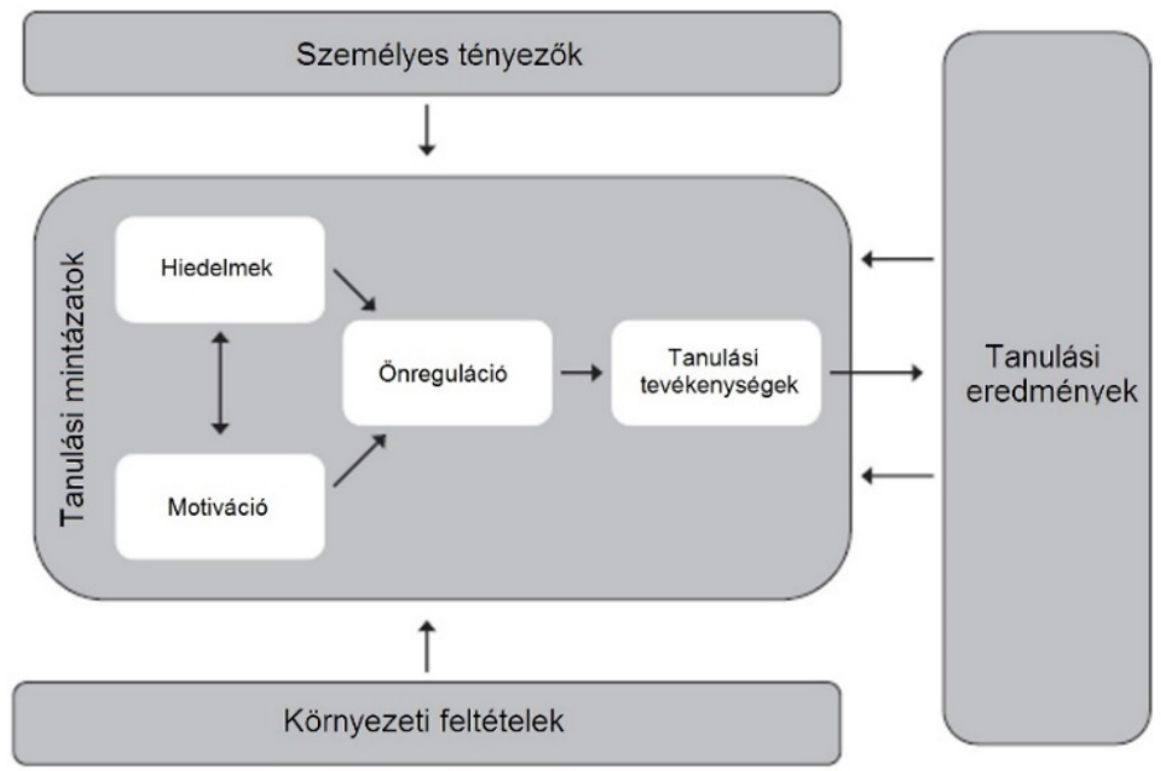

1. ábra: A tanári tanulás modellje (Forrás: Vermunt és Endedjik, 2011)

Vermunt és Endedijk modellje szerint a pedagógusok tanulását olyan - a tanulói tanulás kapcsán is jól ismert - tényezők alakítják, mint a vonatkozó hiedelmek, az önreguláció és a tanulási motiváció. Ezek együttesen értelmezhetők az egyénekre (pedagógusokra) jellemző tanulási mintázatokként, amelyeket érdemben alakítanak személyes és környezeti feltételek. A modell értelmében a tanulási helyzetek eredménye, a kapcsolódó élmények direkt módon hozzákapcsolódnak a későbbi tanulási folyamatok kognitív és affektív tényezőihez, így például erősen alakítják a saját tanulásra vonatkozó hiedelmeket is.

A tanulási eredmények kapcsán eddig annak tacit, gyakorlati jellegét emeltük ki, tekintettel arra, hogy e tanulmány keretében csak az olyan tudásformák kialakulását értelmezzük valós szakmai fejlődésként, amelyek a gyakorlati munka során hasznosulnak. Az ilyen tudás lehetővé teszi többek között, hogy a pedagógusok azonnali és konstruktív választ adjanak az osztálytermek szintjén kialakuló, előre nem látható, sajátos problémahelyzetekben. A pedagógusok szakmai tudásáról azonban ennél jóval árnyaltabb képpel rendelkezünk. Ezzel kapcsolatban érdemes felidézni azt a Lee S. Shulman (1987) nevéhez fúződő, széles körben alkalmazott kategóriarendszert (2. ábra), amelynek elemei mögött jelen van a gyakorlati 
tudás és a reflektív tanulás elmélete nyomán ismertté vált Donald A. Schön hatása is, és amelynek révén lehetővé válik többek között a szakterülethez kapcsolódó és a nevelési-oktatási feladatokhoz kötődő tudás megkülönböztetése (Bullock, 2011).

1. Tárgyi tudás (Content knowledge)

2. Általános pedagógiai tudás (General pedagogical knowledge)

3. Kurrikulumtudás (Curriculum knowledge)

4. Pedagógiai tartalmi tudás (Pedagogical contetn knowledge)

5. A tanulók és sajátosságaik ismerete (Knowledge of learners and their characteristics)

6. A nevelési-oktatási kontextus ismerete (Knowledge of educational contexts)

7. A nevelési-oktatási célok, funckiók és értékek ismerete (Knowledge of education ends, purposes, and values) (Forrás: Shulman, 1987).

E kategóriarendszernek számos változata született, így többek között ismerünk olyan elméletet, amely a kognitív dimenzió (Grossman, 1995) és amely a kontextus szerepe szempontjából (Barnett - Hodson, 2001) értelmezte újra a struktúrát.

A modell kapcsán érdemes röviden kitérnünk a tanulási eredmények mellett megjelenő további három nagy elemre: a tanulás értelmezésére, az egyéni és a környezeti feltételekre. Előbbi kapcsán talán az a leglényegesebb, hogy megkülönböztessük egymástól a létező tudás elsajátítását (adaptív) és az új tudás megteremtését (kreatív) lehetővé tevő tanulási formákat. A pedagógusok szakmai fejlődése mindkét tanulási forma jelenlétét igényli, a hangsúly ezek kiegyensúlyozott és az adott pedagógiai helyzetnek megfelelő megjelenésén van. E formák alkalmazhatóságáról jellemzően a pedagógusok szakmai kompetenciáinak függvényében gondolkodunk: azok, akik egy adott területen alacsonyabb szintű szakmai kompetenciákkal rendelkeznek, inkább igénylik az adaptív, több támogatást nyújtó tanulási folyamatokat, míg akiknek szakmai tudása elér egy kritikus szintet, a valós eredményeket kreatív folyamatokon keresztül képesek csak elérni (Fullan, 2008; Mourshed és mtsai., 2010). Itt azonban már a pedagógusok tanulásának egyéni meghatározóit érintjük, ezen belül is az egyik legfontosabb kérdést: a pedagógusok megelőző szakmai gyakorlatát és tudását. 


\begin{abstract}
Adaptív és kreatív tanulási formák
Az adaptív és kreatív tanulási formák előfordulását „jól illusztrálja az a modell, amely a problémák és a lehetséges megoldások jelenléte szerint kategorizálja a tanulási helyzeteket (Darsø - Høyrup, 2012). Eszerint akkor beszélhetünk kreatív, innovatív vagy fejlesztő tanulásról - amit esetenként expanzív, kéthurkos, vagy transzformatív tanulásként írnak le - ha a résztvevők olyan kereső helyzetben vannak, ahol mind a probléma, mind pedig az arra adható megoldás képlékeny, formálható. Ez a helyzet kedvez az innovációk létrehozásának, az új tudás gyakorlatban történő teremtésének, a korábban nem létező tudást eredményező tanulásnak. Emellett akkor is korábban nem létező tudás létrehozásáról beszélhetünk, ha a probléma azonosítható, de maga a megoldás nem áll rendelkezésre. Ha azonban a probléma értelmezése stabil, a tanulási helyzet elsősorban problémamegoldás szintjén marad, és maga a folyamat kevésbé alkalmas a metaszintet érintő pedagógus kompetenciák fejlesztésére. Ilyenkor adaptív tanulás történik, amely létező megoldások megismerését és integrálását célozza, jól azonosított és kevésbé nyitott problémahelyzetek esetén. Utóbbi jellemzően sajátos módon zajlik a pedagógusok körében: itt az újonnan megismert tudás azonnal hozzákapcsolódik a gyakorlathoz, az elméleti tudás megszerzése és a gyakorlati hasznosítása egyaránt a tanulási folyamat részét képezi."
\end{abstract}

Forrás: Fazekas, 2018, 101. o.

A megelőző szakmai tudás jelentősége túlmutat a megfelelő tanulási formák megválasztásán. A munkahelyi tanulás során a korábbi szakmai gyakorlathoz és az annak alkalmazása mögött meghúzódó paradigmákhoz közvetlenül kapcsolódnak hozzá az újonnan kialakuló ismertek, képességek. A régi és az új találkozása számos feszültséggel járhat, mely feszültségek komoly akadályát képezhetik a valós tanulási eredmények elérésének. Így a tanulási folyamat során a gyors sikerek elmaradása és a kezdeti kudarcok könnyen aktivizálhatják azokat a korai nézeteket, amelyek gátat szabhatnak az új, korszerű megoldások alkalmazásnak. Értve utóbbi alatt többek között a komplex képességfejlesztésre, a tanulás tanításáratanulására, illetve a csoport mint a tanulási kontextus alkalmazására fókuszáló eljárásokat. Emellett fontos hangsúlyozni, hogy a szakmai fejlődés szempontjából a nézetek ütközése nem csupán az egyes pedagógusok, de pedagóguskollektívák, illetve az iskola működését befolyásoló szereplőcsoportok (például a szülők) esetében is különösen meghatározó lehet.

Az egyéni feltételek kapcsán számos egyéb tényező meghatározónak bizonyul, melyek közül érdemes kiemelten kezelni a személyes vélekedéseket és hiedelmeket. A pedagógustanulás affektív oldalával foglalkozó Monique Boekaerts elmélete alapján a sikeres munkahelyi tanulás nyolc fó érzelmi feltétele rajzolódik ki előttünk: (1) az elvárt feladatok teljesítésével kapcsolatos kompetenciaérzet, (2) a 
cselekvések és az elért eredmények közötti direkt kapcsolatok meglátása, (3) a feladatok értékes, fontos, izgalmas, és releváns jellegének felfedezése, (4) pozitív megelőző tanulási élmények, (5) a kapcsolódó negatív érzelmek (például a szorongás) hiánya, (6) az érzelmi intelligencia - érzelmek erősségének, időtartamának és kifejezésmódjának befolyásolására való képesség, (7) a meglévő erőforrásokkal való megfelelő gazdálkodás képessége, valamint (8) a támogató tanulási környezet érzete (Boekaerts, 2010). Az ImpAla kutatás elméleti megalapozása (Fazekas, 2018) e modell értelmezése során kiemelte: a pedagógusok szakmai fejlődését segíteni hivatott tanulási helyzetek az érzelmek széles skáláját aktivizálhatják. Egészen más érzelmi viszonyulást idézhetnek elő a korai sikereket vagy a társas tanulás lehetőségét biztosító tanulási helyzetek, és azok a kötelező képzések, amelyek iránt, vagy amelyek alkalmazott módszerei iránt kevéssé fogékonyak a résztvevők.

A személyes feltételek mindkét fenti aspektusában kiemelt szerephez jutott a szakmai fejlődés kontextusa, amely Vermunt és Endedijk (2011) modellje szerint is különös figyelmet érdemel. Ez számos tényezőt magában foglalhat, lényegében ide sorolható a szociális, a rendszerszintű és az infrastrukturális környezet és annak hatásának egésze, beleértve a szülői közösség viselkedését, a fejlesztési programok megvalósulását, és a horizontális tudásmegosztást lehetővé tevő hálózatokat. A kontextus szerteágazó rendszeréből az alábbiakban a munkahelyi környezettel foglalkozunk, mivel korábbi kutatások eredményei alapján - beleértve többek között az alább bemutatott kutatásokat is - ez az a környezet, amely a leginkább erős és közvetlen hatással van a pedagógusok szakmai fejlődésének alakulására. Bár a pedagógusok tanulása egyéni és társas formában is megvalósulhat, a tanári tanulást annak eredményessége és minősége szempontjából vizsgáló elemzések szerint az interakciókon keresztül megvalósuló folyamatok tekinthetők a legmagasabb szintű, valós eredményeket hozó tanulási formának (lásd például Meirink és mtsai, 2009; Bakkenes és mtsai, 2010; Saqipi - Rexhaj, 2012). A munkahelyen történő tanulás számos eltérő helyzetbe ágyazottan létrejöhet, ilyen többek között a formális képzés, a projekt-megvalósítás, vagy a partnerekkel való közös munka. Azokról az iskolákról gondolhatjuk, hogy képesek e tanulási folyamatokat megfelelően támogatni, amelyek maguk is tanulószervezetként működnek. Azokat a szervezeteket tekinthetjük ilyennek, amelyeket tanulás fókuszú vezetés irányít, ahol a szervezeti célok és a jövőkép a munkatársak között általánosan ismertek és támogatottak, ahol intenzív a tudásmegosztás, erős hálózati és partneri kapcsolatok működnek, és ahol a pedagógusok bizalmi légkörben dolgoznak, fele- 
lősséget vállalnak saját fejlődésükért, illetve utóbbi érdekében kockázatot is vállalnak (Anka és mtsai, 2016). Az ilyen szervezetek, pedagógustanulást segítő munkahelyi környezetek kialakulása hosszú folyamat, mely előtérbe helyezi a szervezeti tanulás kérdését is.

Az alábbiakban ezek alapján vizsgáljuk korábbi kutatások adatbázisainak másodelemzése segítségével a tanári tanulás szervezeti, csoportos és egyéni szintjét. A fókuszunkban elsősorban a tanári tanulásként értelmezett innovációs és fejlesztési tevékenység áll, amelynek figyelembe vesszük egyéni szintű vonatkozásait, de szervezeti szintü kontextusát is.

\section{A másodelemzésbe bevont adatbázisok bemutatása}

Az Innova kutatás a helyi szintủ újítások keletkezésének, terjedésének és terjesztésének sajátosságait vizsgálta. Az elsőkörös adatfelvétel 2016 őszén zajlott a teljes oktatási rendszerben (óvodától a doktori iskolán át a piaci képzőkig) és összesen 4853 intézménytől ${ }^{4}$ érkezett használható adat (a továbbiakban ezt az adatfelvételt Innova1 névvel jelöljük). A kérdőívet az intézmények vezetői töltötték ki az egész szervezetre vonatkozóan, így elsősorban szervezeti szintű, vezetői perspektíva jelenik meg az adatokban. A kutatás az innovációt a rutintól való eltérő működésként értelmezte, a sokszor láthatatlan, munkavégzés közbeni, problémamegoldás során megjelenő újításokat, kísérletezést előtérbe helyezve (Fazekas - Halász - Horváth, 2017).

2018 tavaszán a kutatás megismételte az adatfelvételt egy kibővített kérdőívvel, ugyanúgy, szervezeti szinten, de ezúttal kiegészítve egy egyéni szintủ kérdőívvel, amelyet a vezetők továbbítottak az intézményben dolgozó pedagógusok, oktatók számára (a továbbiakban ezeket az adatfelvételeket Innova2 névvel jelöljük). E második adatfelvétel nyomán keletkezett adatbázisok 1974 szervezeti perspektívát feltáró, vezető által kitöltött, míg 4025 egyéni innovációs működést vizsgáló, beosztott kolléga által kitöltött kérdőív adatait tartalmazzák. ${ }^{5}$

\footnotetext{
${ }^{4}$ Az Innova1 adatbázis mintájára vonatkozóan a kitöltők besorolása alapján 1724 intézmény múködtet iskolai előtti nevelési profilt, 1123 intézmény bír alapfokú oktatási profillal, 103 intézmény biztosít középfokú általános, 193 intézmény pedig középfokú szakmai képzést. 61 intézmény vegyesen biztosít középfokú általános és szakmai képzést, míg 1037 intézmény valamilyen vegyes profillal rendelkezik. Az adatbázisban szerepel továbbá 446 felsőoktatási intézet/tanszék, 58 doktori iskola, 99 piaci vagy non-pro fit képzőintézmény és 9 nem beazonosítható felsőoktatási kitöltő. A teljes sokaságnak kiküldött kérdőívekhez képest a visszaküldési arány 27,3\%. (Nagy-Rádli, 2018).

${ }^{5} \mathrm{Az}$ Innova2 szervezeti adatbázis esetén 1619 köznevelési intézménytől származik adat: 846 intézmény rendelkezik iskola előtti nevelési profillal, 591 intézmény biztosít alapfokú nevelést, 94 intézmény rendelkezik középfokú általános, 135 intézmény pedig középfokú szakmai képzési profillal, továbbá 123 intéz-
} 
A kérdőívek általános logikája, hogy az első blokkban a szervezetről, a szervezet újító gyakorlatáról, aktivitásáról tett fel általános kérdéseket (subject method), majd pedig arra kérte a kitöltőt, hogy nevezzen meg és írjon le egy konkrét innovációt az intézmény elmúlt időszakából. A kérdőív második része kifejezetten erre az újításra fókuszálva tett fel kérdéseket (object method). Ez a megközelítés összhangban van az innovációk mérésének alapkönyvének számító Oslo kézikönyv legújabb kiadásával (OECD/Eurostat, 2018).

Ahogyan az innováció fogalmát értelmezte a kutatás (utalva elsősorban a láthatatlan, munkavégzés közbeni problémamegoldás során megjelenő újításokra), az értelmezhető a folyamatos szakmai fejlỏdés egyik tevékenységeként is, hiszen ez egyfajta kísérletezésből, saját munkára való reflexióból álló tevékenység. Másrészről az adatbázisokban olyan változók is szerepelnek, amelyek direkt módon a pedagógusok szakmai fejlődéséről szólnak. Ezekre alapozottan vizsgálható például, hogy az innováció területén aktív intézmények körében miként alakult a kollégák szakmai felkészültsége, vagy hogy az újításokat milyen tudásmegosztási formák kísérték.

Az Innova1 és az Innova2 vezetői kérdőíve elsősorban a szervezeti szintű folyamatok, a kontextus megragadására alkalmas. A két adatfelvétel között eltelt idő arra is lehetőséget ad, hogy az ez idő alatt zajlott változásokat is vizsgáljuk. Az Innova2 egyéni kérdőívének másodelemzése emellett a pedagógusok tanulásának, kísérletezésének és hosszabb távon fenntarthatónak bizonyuló innovatív megoldásainak vizsgálatát is lehetővé teszi a fent bemutatott általános működésre és konkrét innovációra vonatkozó kérdések mentén. Olyan háttérváltozók segíthetik e folyamatok megértését, mint a pedagógusok szakmai hálózatokban, tudásmegosztó közösségekben való részvétele, kvalifikációja vagy nyelvtudása.

A következő táblázatban (1. táblázat) összegezzünk a vizsgált adatbázisok legfontosabb adatait az áttekinthetőség kedvéért.

mény biztosít fejlesztő, gyógypedagógiai nevelést-oktatást, 195 intézmény pedig egyéb profillal rendelkezik. Az egyéni szintủ kérdőívből 2911 kitöltő dolgozik valamilyen állami köznevelési intézményben, 516 pedig nem állami fenntartású köznevelési intézményben. A minta részletesebb megoszlása megtalálható az adatfelvételről szóló gyorsjelentésben (Nagy-Rádli - Szarka-Bögös, 2019). 
Pedagógusképzés • 18(46), 2019/3-4.

\begin{tabular}{|c|c|c|c|}
\hline $\begin{array}{l}\text { Adatbázis } \\
\text { megnevezése }\end{array}$ & Vizsgálati időszak & Minta & Támogatás/háttér \\
\hline Innova1 & 0 & 0 & \\
\hline Innova2 & 0 & $\begin{array}{c}2 \text { adatbázis: } \\
4025 \text { oktatási } \\
\text { intézményben dolgozó } \\
\text { pedagógus/oktató/ } \\
\text { képző (egyéni szint), } \\
1974 \text { oktatási } \\
\text { intézmény vezetője } \\
\text { (szervezeti szint) }\end{array}$ & $\begin{array}{c}\text { OTKA/NKFIH } 115857 \\
\text { „A helyi innovációk } \\
\text { keletkezése, terjedése } \\
\text { és rendszerformáló } \\
\text { hatása az } \\
\text { oktatási ágazatban” }\end{array}$ \\
\hline
\end{tabular}

1. táblázat: A másodelemzésbe bevont adatbázisok legfontosabb adatai

\section{Az innovációk keletkezésének és terjedésének szervezeti és egyéni aspektusai a folyamatos szakmai fejlődéssel összefüggésben}

Az Innova adatbázis feldolgozása e tanulmány születésekor még folyamatban volt, és az elérhető eredmények még nem adtak átfogó képet az eltérő adatbázisok alkalmazhatóságáról a pedagógusok szakmai fejlődése vonatkozásában. Ezért nem választottunk preferált elemzési szintet, hanem párhuzamosan, egymástól elkülönítve vizsgáltuk a szervezeti és az egyéni adatokat. Az alábbiakban elsőként a szervezeti mutatókból kirajzolódó, majd ezt követően az egyéni adatok elemzése során megragadható dinamikákat ismertetjük.

\section{Az innováció és a pedagógusok tanulásának összefüggései szervezeti szinten}

Az Innova kutatás adatbázisai szervezeti (intézményvezetői kitöltés a szervezetre vonatkozó kérdésekre) és egyéni (egyéni pedagógusi kitöltés saját gyakorlatukra vonatkozóan) szinten is értelmezhetők. Jelen tanulmány keretében a tanári tanulás egyik formájaként tekintünk az innovációra (Halász - Horváth, 2017).

Az Innova szervezeti adatbázisában a vezetők megjelölhették, hogy alapvetően milyen tényezők motiválják az intézményben az újítások létrejöttét, átvételét. Úgy is értelmezhetjük ezt a kérdést, hogy milyen tényezők keretében kísérleteznek, újítanak a pedagógusok, vagyis mi indukálja elsősorban a tanulásukat. A kérdőívben az alábbi tényezők szerepeltek:

1. Olyan újítás, amivel valamilyen problémára (például tanulói összetétel változása, tanulási nehézségek, motiválási problémák, tanulmányi eredmények romlása stb.) próbáltunk választ adni. 
2. Olyan újítás, amely külső ösztönzésre vagy elvárásra (például központi szabályozás változása, uniós fejlesztési programokban való részvétel, fenntartói igény, partnerek igényei stb.) történt.

3. Olyan újítás, amelyet más kollégák, intézmények/szervezetek sikeres gyakorlata inspirált.

4. Olyan újítás, amelyet továbbképzésen megismert, korábban nem alkalmazott új megoldások megismerése nyomán kezdtünk el alkalmazni.

5. Olyan újítás, amelyet azért vettünk át másoktól, mert vonzónak találtuk a hozzá kapcsolódó szakmai megközelítést.

6. Olyan újítás, amelyet azért vettünk át, mert az intézményünk/szerveztünk tagja lett valamilyen ezt támogató hálózatnak.

7. Olyan újítás, amely nem szándékolt, véletlen módon keletkezett.

A motiváció leggyakoribb forrásaként a kitöltők a továbbképzéseket, a problémára való reakciót és a külső ösztönzést jelölték. A kiemelt területek között így megjelenik a formális továbbképzések világa, valamint az informálisabb, munkavégzés közbeni tanulás dimenziói (problémamegoldás). Továbbá a külső ösztönzés kapcsán felmerül a rendszerkörnyezet szerepe, illetve emellett a különböző fejlesztési programokban való részvétel is mint olyan terület, amely tanulásra ösztönözheti vagy kényszerítheti a pedagógusokat egy intézményben (lásd Nagy-Rádli - Szarka-Bögös, 2019).

A tanulás motivációja mellett érdemes megnézni, hogy az újítási gyakorlat leggyakrabban milyen területre irányul. A kérdőívben az alábbi válaszlehetőségeket adtuk meg, ahol az intézményvezetők megjelölhették, hogy az adott területen milyen gyakori az intézmény újító tevékenysége:

1. A foglalkozások, tanórák tervezéséhez és megvalósításához kapcsolódó módszerek és eszközök

2. A tanulók, hallgatók, gondozottak teljesítményének értékelése vagy mérése

3. A foglalkozásokon vagy tanórákon kívüli tevékenységek (például szakkörök, terepmunka, hallgatók önálló otthoni munkája)

4. Technikai eszközök használata a nevelésben, oktatásban, képzésben

5. A szervezet belső működése (például munkaszervezés, gazdálkodás, vezetés, az infrastruktúra működtetése stb.) 
6. A szervezet működését, vezetését érintő technikai, informatikai megoldás (például elektronikus nyilvántartások, belső levelezés, vezetői információs rendszer)

7. A partnerekkel/igénybevevőkkel (például helyi közösség, szülők, munkaadók, civil szervezetek, képzéseket igénybe vevők) való külső kapcsolatok

8. A tanulók (hallgatók, gondozottak) kompetenciáinak, képességeinek eredményesebb fejlesztése

9. A tehetségek gondozása

10. A hátrányos helyzetűek, leszakadók oktatása/nevelése

A felsorolt területek közül a leggyakrabban a hátrányos helyzetű diákok oktatására, a tehetségek gondozására, az oktatás területén való technikai eszközök alkalmazására, illetve kompetenciafejlesztésre vonatkozó újításokat jelöltek meg a kitöltők, mint amelyek leggyakrabban valósulnak meg az intézményben (lásd Nagy-Rádli - Szarka-Bögös, 2019).

Érdemes az előbb említett két dimenziót összefüggéseiben vizsgálni, vagyis azt feltárni, hogy az adott motivációval rendelkező tanulási folyamat során leggyakrabban milyen területre irányult a pedagógusok újítási, tanulási folyamata. Kereszttábla elemzések alapján minden pár esetében szignifikáns összefüggés mutatható ki, Cramer-féle V érték alapján pedig az összefüggés általában kicsi vagy közepes mértékű (0,2-0,3 közötti értékek). Más kollégák gyakorlata elsősorban tanórai tevékenységhez, szervezeti működéshez kapcsolódó IKT megoldásokhoz és kompetenciafejlesztéshez kapcsolódó újításokat inspirált. Véletlen, nem szándékolt újítások pedig elsősorban az értékelési gyakorlathoz, tanórán kívüli tevékenységekhez, tanórához kötődő digitális megoldásokhoz és a szervezeti mủködéshez kapcsolódtak. A szakmai támogató hálózatok kapcsán pedig elsősorban a tehetséggondozás és a hátrányos helyzetű tanulók oktatásához kapcsolódó innovációk jelentek meg. Az elemzések alapján e felsorolt motivációs tényezők bizonyultak meghatározónak.

Az Innova kutatás fókuszában az oktatási innovációk keletkezésének és terjedésének vizsgálata áll, így a kérdőívben található változók alapján létrehoztunk olyan összetett mutatót, amely a szervezet innovatív viselkedését írja le (Horváth, 2017). Ez az úgynevezett Összetett Innovációs Mutató (ÖIM), amely a teljes mintát tekintve $-12,85$ és 20,91 között vehet fel értékeket, átlaga 0,13 (95\% CI [-0,19; 0,44]), szórása pedig 5,61. A korábbiakban feltárt dimenziókban vizsgáltuk az ÖIM 
átlagának alakulását független mintás t-próba segítségével. Először az innovációt kiváltó tényezők alapján mutatjuk ezt be a 2 . táblázatban.

\begin{tabular}{|c|c|c|c|c|}
\hline Dimenzió & $\begin{array}{l}\text { Csoport- } \\
\text { átlagok } \\
\text { különbsége } \\
{[0-1]} \\
\end{array}$ & 95\% CI & $t(d f)$ & Hedge's g \\
\hline $\begin{array}{l}\text { Olyan újítás, amelyet továbbképzésen } \\
\text { megismert, korábban nem alkalmazott új } \\
\text { megoldások megismerése nyomán } \\
\text { kezdtünk el alkalmazni. }(0 \text { - nem } \\
\text { jellemz̋̋; } 1 \text { - jellemző) }\end{array}$ & $-5,26$ & $\begin{array}{c}{[-5,87} \\
-4,66]\end{array}$ & $\begin{array}{c}-17,15 \\
(836,37) \\
* *\end{array}$ & 1,05 \\
\hline $\begin{array}{l}\text { Olyan újítás, amivel valamilyen } \\
\text { problémára próbáltunk választ adni. (0 - } \\
\text { nem jellemző; } 1 \text { - jellemző) }\end{array}$ & $-5,96$ & $\begin{array}{c}{[-6,53} \\
-5,4]\end{array}$ & $\begin{array}{c}-20,61 \\
(1231)^{* *}\end{array}$ & 1,23 \\
\hline $\begin{array}{l}\text { Olyan újítás, amelyet azért vettünk át, } \\
\text { mert az intézményünk/szerveztünk tagja } \\
\text { lett valamilyen ezt támogató hálózatnak. } \\
(0-\text { nem jellemző; } 1 \text { - jellemző) }\end{array}$ & $-6,39$ & $\begin{array}{c}{[-7,24} \\
-5,53]\end{array}$ & $\begin{array}{c}-14,63 \\
(1231)^{* *}\end{array}$ & 1,23 \\
\hline $\begin{array}{l}\text { Olyan újítás, amelyet más kollégák, } \\
\text { intézmények/szervezetek sikeres } \\
\text { gyakorlata inspirált. }(0-\text { nem jellemző; } 1 \\
\text { - jellemző) }\end{array}$ & $-6,63$ & $\begin{array}{c}{[-7,29} \\
-5,97]\end{array}$ & $\begin{array}{c}-19,66 \\
(1231) * *\end{array}$ & 1,35 \\
\hline $\begin{array}{l}\text { Olyan újítás, amelyet továbbképzésen } \\
\text { megismert, korábban nem alkalmazott új } \\
\text { megoldások megismerése nyomán } \\
\text { kezdtünk el alkalmazni. ( } 0 \text { - nem } \\
\text { jellemző; } 1 \text { - jellemző) }\end{array}$ & $-5,26$ & $\begin{array}{c}{[-5,87} \\
-4,66]\end{array}$ & $\begin{array}{c}-17,15 \\
(836,37) \\
* *\end{array}$ & 1,05 \\
\hline
\end{tabular}

Az innovációk mögött rejlő motivációk kapcsán megállapítható, hogy minden esetben szignifikáns, nagy hatásméretű különbség figyelhető meg a csoportok között, tehát ahol jelen van valamilyen motiváló hatás, ott a szervezet összetett innovációs mutatója nagyobb értéket mutat. Jól látható, hogy olyan területek, amelyek összefüggésben állhatnak a tanári tanulással (például továbbképzések, problémamegoldás, szakmai hálózatban való részvétel, tudásmegosztás), azok pozitív összefüggést mutatnak az intézmény újító gyakorlatával.

Ha további változók keretében vizsgáljuk ugyanezt a kérdést, akkor hasonló mintázatokat láthatunk. Az adatbázis alapján lehetőség van feltárni például azt is, hogy milyen innovációs mutatóval rendelkeznek azok a szervezetek, ahol az elmúlt időszakban a vezető észlelése alapján sikerült javítani a munkatársak felké- 
szültségét, ahol az intézmény kapcsolódott valamilyen konkrét hálózathoz vagy ahol a munkatársak nyitottak az újításokra. Ezt mutatja a 3. táblázat.

\begin{tabular}{|c|c|c|c|c|}
\hline Dimenzió & $\begin{array}{l}\text { Csoport-átlagok } \\
\text { különbsége [0-1] }\end{array}$ & $95 \%$ CI & $t(d f)$ & Hedge's g \\
\hline $\begin{array}{l}\text { A munkatársak felkészültségének } \\
\text { jelentősebb változása }(0 \text { - nem történt } \\
\text { ilyen; } 1 \text { - történt ilyen })\end{array}$ & $-2,76$ & 0 & 0 & 0,51 \\
\hline $\begin{array}{l}\text { Az intézmény/szervezet kapcsolódása } \\
\text { valamilyen hálózathoz, partnerségi } \\
\text { kapcsolatrendszerhez ( } 0 \text { - nem történt } \\
\text { ilyen; } 1 \text { - történt ilyen) }\end{array}$ & $-3,78$ & 0 & 0 & 0,71 \\
\hline $\begin{array}{l}\text { A munkatársak nyitottak az újításokra } \\
(0-\text { nem jellemző; } 1-\text { jellemző })\end{array}$ & $-1,8$ & 0 & 0 & 0,32 \\
\hline
\end{tabular}

Látható, hogy az előző táblázathoz képest, bár szignifikáns különbségekről beszélünk, a hatásméret mutató kicsi vagy közepes mértékủ. A három változó közül a hálózathoz vagy partnerségi kapcsolatrendszerhez való kapcsolódás mutat nagyobb hatásmérettel különbséget az intézmények innovációs tevékenységében. Ettől függetlenül a többi összefüggés is fontos szempontokat mutat, hiszen alátámasztják, hogy fontos, hogy a munkatársak nyitottak legyenek az újításokra, illetve az, ha a pedagógusok tanulnak, fejlődnek, javul a felkészültségük, az nagyobb innovációs aktivitással jár együtt.

Végül érdemes kitérni a fenti sémában olyan változókra, amelyek azt írják le, hogy az intézmény részt vett-e valamilyen fejlesztési programban az elmúlt időszakban. Ezek a fejlesztési programok stimulálhatnak különböző újításokat, így változásra, alkalmazkodásra és tanulásra késztetve a pedagógusokat. Ezeket az összefüggéseket mutatja a 4. táblázat. 


\begin{tabular}{|c|c|c|c|c|}
\hline Dimenzió & $\begin{array}{l}\text { Csoport-átlagok } \\
\text { különbsége [0-1] }\end{array}$ & $95 \% \mathrm{CI}$ & $t(d f)$ & Hedge's g \\
\hline $\begin{array}{l}\text { Olyan program, amelyben a } \\
\text { korábbitól eltérő tananyagot, } \\
\text { taneszközt, pedagógiai módszereket } \\
\text { kellett alkalmazni }(0 \text { - nem történt } \\
\text { ilyen; } 1 \text { - történt ilyen) }\end{array}$ & $-4,95$ & 0 & 0 & 0,96 \\
\hline $\begin{array}{l}\text { Olyan program, amelyben saját } \\
\text { magunknak kellett új tananyagot, } \\
\text { taneszközt, pedagógiai módszereket } \\
\text { létrehozni }(0 \text { - nem történt ilyen; } 1 \\
\text { - történt ilyen) }\end{array}$ & $-5,46$ & 0 & 0 & 1,06 \\
\hline $\begin{array}{l}\text { Olyan program, amelyben } \\
\text { képzéseken kellett részt venni ( } 0 \text { - } \\
\text { nem történt ilyen; } 1 \text { - történt ilyen) }\end{array}$ & $-4,38$ & 0 & 0 & 0,85 \\
\hline $\begin{array}{l}\text { Olyan nemzeti fejlesztési program, } \\
\text { amely az Európai Unió } \\
\text { támogatásával zajlott (pl. HEFOP, } \\
\text { TÁMOP, EFOP) (0 - nem történt } \\
\text { ilyen; } 1 \text { - történt ilyen) }\end{array}$ & $-3,62$ & 0 & 0 & 0,68 \\
\hline $\begin{array}{l}\text { Olyan program, amely az Európai } \\
\text { Unió oktatási programjainak } \\
\text { keretében zajlott (például Erasmus, } \\
\text { Comenius, Leonardo, Grundtvig) ( } 0 \\
\text { - nem történt ilyen; } 1 \text { - történt } \\
\text { ilyen) }\end{array}$ & $-4,35$ & 0 & 0 & 0,8 \\
\hline
\end{tabular}

A táblázat adatai alapján megállapítható, hogy a különböző programokban való részvétel alapján szignifikáns és általában nagy hatásméretű különbség mutatkozik az intézmények innovációs aktivitásában. Érdemes megfigyelni, hogy nagyobb a különbség az Európai Unió oktatási programjainak keretében zajlott programokban való részvétel (például Comenius), mint az Európai Unió támogatásával megvalósult programok (HEFOP, TÁMOP, EFOP) esetén. A legnagyobb hatásméretű különbséget az a tényező mutatja, amikor az intézményeknek saját maguknak kellett valamilyen tananyagot, taneszközt vagy pedagógiai módszert létrehozni, amely értelemszerűen fontos forrása lehet a tanári tanulásnak.

\section{Az innováció és a pedagógusok tanulásának összefüggései egyéni szinten}

$\mathrm{Az}$ Innova kutatás kérdőívei egyéni szinten is több olyan kérdést tartalmaztak, amelyek a pedagógusok és oktatók (a továbbiakban együttesen pedagógusok) innovatív múködését próbálták feltárni. Tekintettel arra, hogy e kutatás az innová- 
ciókat múködtető mechanizmusokat vizsgálta, a pedagógusok szakmai fejlődése a kísérletezés során kialakuló felfedezési és tanulási folyamatok kapcsán került előtérbe. A sikeres és kevésbé sikeres tanulási utak elsősorban ezen innovációk észlelt eredményességén keresztül ragadhatók meg. A kapcsolódó kérdésekre adott válaszok a megkérdezett pedagógusok személyes vélekedését tükrözik. Az Innova egyéni szintű kérdőív - a vezetőihez hasonlóan - két meghatározó blokkból állt. Az első az innovációs tevékenységről általánosan kérdezte a válaszadót, a második pedig egy szabadon választható innováció megvalósulására vonatkozóan gyüjtött információkat.

A kérdőív első része többek között kiterjedt a saját szakmai eredményességről, annak változásáról alkotott általános képére is, ami különösen meghatározó jellemzője a pedagógusok innovatív múködésének - és kapcsolódó tanulási folyamatainak - feltérképezése céljából vizsgált sokaságnak. A kérdőív a válaszadókat arra kérte, hogy kollégáikhoz viszonyítva becsüljék meg saját munkájuk eredményességét. ${ }^{6} \mathrm{~A}$ válaszadó pedagógusok $65,5 \%$-a kollégáihoz hasonlónak látta munkája eredményességét, 33,3\%-a eredményesebbnek, míg 1\%-a jelezte hogy, kollégáihoz képest kevésbé eredményes. Emellett a kutatás kiterjedt a szervezeti eredményesség változásának feltárására is. ${ }^{7} \mathrm{E}$ kérdések nyomán nem az egyes pedagógusról, hanem annak a pedagóguskollektívának az egészéről kapunk képet, amelyen belül a válaszadó a munkahelyi környezetében müködik. ${ }^{8} \mathrm{~A}$ kapcsolódó adatokból azt látjuk, hogy a válaszadók egy jól megragadható csoportja (703 pedagógus, azaz 18,8\%) jelezett eredményességromlást (3. ábra). Fontos itt megjegyeznünk: az, hogy a kérdőív nem tesz különbséget az eredményesség különböző területei között, feltételezhetően erősíti az eltérő értelemzések és a pedagógusok személyes, érzelmi viszonyulásának hatását a jelzőszámok alakulására. Az eredményességváltozás érzetének feltárását erősíti továbbá az is, hogy a kérdés nem konkretizálja a vizsgált periódust az „elmúlt években”-nél pontosabban.

\footnotetext{
${ }^{6}$ Feltett kérdés: Hogyan ítéli meg saját munkájának eredményességét? A legtöbb kollégámhoz képest eredményesebben végzem a munkámat (1); A munkám eredményessége hasonló a legtöbb kollégáméhoz (2); A kollégáim többsége nálam eredményesebben végzi a munkáját (3); Nem tudok, nem kívánok válaszolni a kérdésre (99).

${ }^{7} \mathrm{Az}$ Innova elődjének tekinthető ImpAla kutatásban a pedagógusok a saját szakmai munkájuknak eredményességváltozását feltáró kérdésben elzárkóztak a romló tendenciák jelölésétől, feltételezhetően e dinamikát az önvédő mechanizmusok nem engedik megjeleníteni. Így az Innova kutatásban a személyes eredményesség változása helyett a szervezeti eredményesség formálódására kérdezett rá a kérdőív.

${ }^{8}$ Feltett kérdés: Az alábbiak közül melyik állítás jellemző leginkább arra az intézményre/szervezetre, amelyben a munkáját végzi? Felsőoktatási intézmény esetében a szervezeti egységre (tanszék, intézet, központ stb.) vonatkozik a kérdés.
} 


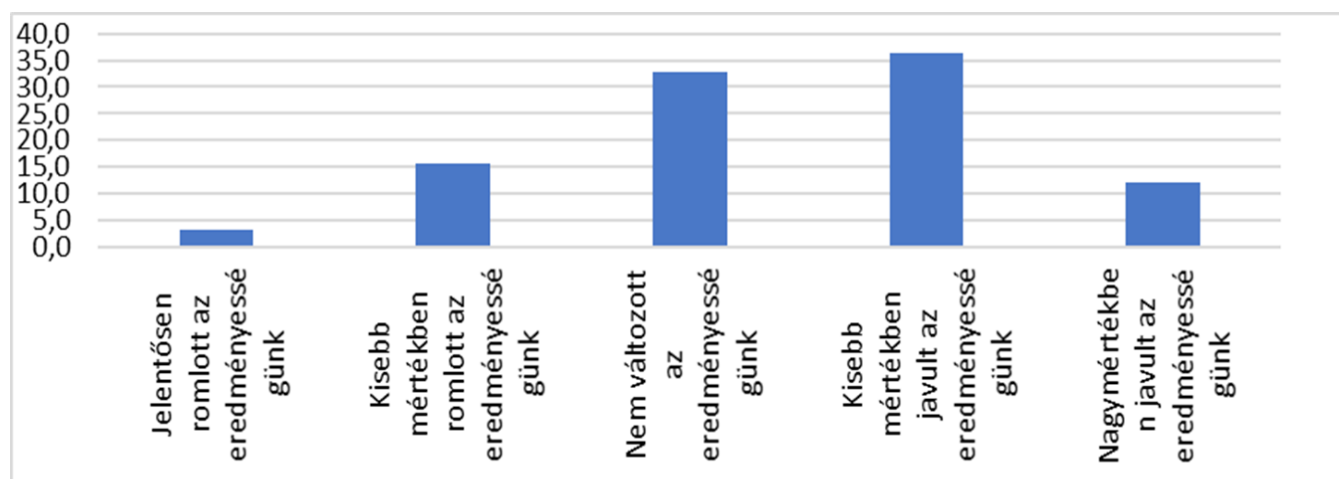

2. ábra: A munkahely eredményességének változása - a válaszadó beosztottak véleménye alapján (\%) $(\mathrm{N}=3732)$

A kísérletezésen alapuló tanári tanulás (észlelt) eredményességének vizsgálatára a második kérdésblokk adott inkább kedvező terepet, mindemellett az első rész is tartalmazott kapcsolódó kérdéseket. Így például vizsgálta, hogy a kitöltést megelőző tíz évben előfordult-e, hogy a megkérdezettek által kitalált új megoldás javította munkájuk eredményességét, ${ }^{9}$ amellyel a válaszadók csupán $15 \%$-a nem értett egyet. Az e blokkban megjelenő kérdések legerősebban arra fókuszáltak, hogy a válaszadók milyen gyakorisággal vettek részt különböző típusú fejlesztésekben, munkahelyi tanulási helyzetekben. A kapcsolódó változók esetében a vélekedések, hiedelmek feltárása kevésbé kapott kiemelt hangsúlyt, ehelyett a fejlesztő tevékenységek, tanulási és tudásmegosztási helyzetek gyakoriságának megbecsülésre kérték a kérdések a válaszadókat. Az egyik kapcsolódó kérdés ${ }^{10}$ nyomán azt láthatjuk, hogy a mintába tartozó pedagógusok egy jól megragadható csoportját elérték külső támogatással megvalósuló fejlesztési programok. A pedagógusok 34\%-a vett részt olyan programban, amelynek során saját magának kellett új tananyagot, taneszközt, pedagógiai módszert létrehoznia, 54\%-a olyanban, ahol a korábbitól eltérő tananyagot, taneszköz, pedagógiai módszert kellett alkalmaznia,

\footnotetext{
${ }^{9}$ Feltett kérdés: Előfordultak-e az alábbiak az Ön munkájában az elmúlt tíz évben? Kérjük, a lista minden tételéhez jelölje válaszát! /Valamilyen általam kitalált új megoldás jelentősen javította a munkám eredményességét./ Nem történt ilyen (1); Igen, egy-két alkalommal történt ilyen (2); Igen, több ilyen történt (3); Igen, nagyon sok ilyen történt (4); Nem tudok, nem kívánok válaszolni a kérdésre (99).

${ }^{10}$ Feltett kérdés: „Részt vett-e Ön személyesen az elmúlt tíz évben olyan fejlesztési programban, projektben, amelyre az intézménye/szervezete pályázati vagy egyéb úton külső támogatást kapott? Kérjük, a lista mindegyik tételéhez jelölje válaszát!” Válaszok: „Olyan programban, amelyben a korábbitól eltérő tananyagot, taneszközt, pedagógiai módszereket kellett alkalmaznom, Olyan programban, amelyben saját magamnak kellett új tananyagot, taneszközt, pedagógiai módszereket létrehoznom, Olyan programban, amelyben képzéseken kellett részt vennem"
} 
68,7\%-a pedig olyanban, ahol képzésen kellett részt venni. A kérdőív a külső támogatásoktól függetlenül is megvalósítható, a munkahelyi tanulásnak intenzív terepet adó platformokra is rákérdezett. Az olyan klasszikus formák, mint a munka eredményességét szolgáló továbbképzéseken való részvétel, a szakirodalomi és az interneten keresztüli tájékozódás mellett többek között vizsgálta az új szakmai megoldásokat létrehozó munkacsoportokban való részvételt, a kollégák tanítását, a tanítási, nevelési megoldásokról szóló továbbképzések, előadások tartását, tanácsadói és értékelői szerep betöltését. ${ }^{11} \mathrm{Az}$ adatok szerint a pedagógusok 41,3\%-a tanította kollégáit az eredményesség növelését támogató gyakorlatokra továbbképzés vagy előadás formájában. 19,2\%-uk tanácsadóként, míg 21,4\%-uk értékelőként segítette más intézményben dolgozó kollégái munkáját. 71,3\% jelölte, hogy részt vett olyan intézményen belül müködő munkacsoportban, munkaközösségben, amely a munka eredményesebbé tételét szolgáló új szakmai megoldások kidolgozásán dolgozott. Továbbképzéseken való részvételt a válaszadók 79,8\%-a, a szakirodalomból való tanulást $87 \%$-a, az interneten keresztül való értesülést $91 \%$-a jelölte.

A második, konkrét innovációra vonatkozó blokk a kiválasztott innováció megvalósulását, illetve a pedagógusok tanulásának feltételezhető hatásait próbálta feltárni. Az e területekre irányuló kérdések közül azok, amelyek az eredményességre és annak változására fókuszálnak, általánosan kezelik a pedagógiai eredményesség fogalmát, nem differenciálják azt. Arra a kérdésre, hogy „Hogyan hatott az Ön munkájának eredményességére a kiválasztott újítás, illetve az ennek nyomán kialakult új gyakorlat?” a válaszadók $71 \%$-a reagált úgy, hogy jelentős, vagy nagyon jelentős mértékben javította azt, míg összesen 3\% jelezte, hogy nem volt hatással, vagy éppen negatív, káros hatással volt munkája eredményességére (4. ábra).

\footnotetext{
${ }^{11}$ Feltett kérdés: „Az elmúlt tíz évben előfordultak-e, és ha igen, milyen gyakran az alábbiak az Ön személyes gyakorlatában?” „Részt vettem olyan, intézményünkön belül müködő munkacsoport, munkaközösség munkájában, amely a munkánk eredményesebbé tételét szolgáló új szakmai megoldások kidolgozásán dolgozott; Kollégáknak továbbképzést, előadást tartottam olyan tanítási, nevelési megoldásokról, amely a munkájuk eredményesebbé tételét szolgálta; Tanácsadóként segítettem más intézményekben dolgozó kollégák munkáját; Értékeltem más intézmények vagy más intézményekben dolgozó kollégák munkáját; Olyan továbbképzésen vettem részt, ahol a munkám eredményességét érdemben javító új megoldásokat ismertem meg; A szakirodalomból értesültem olyan új szakmai megoldásokról, amelyeket a saját munkámban is alkalmazni tudtam; Az interneten keresztül értesültem olyan új szakmai megoldásokról, amelyeket a saját munkámban is alkalmazni tudtam” „Nem történt ilyen (1); Igen, egy-két alkalommal történt ilyen (2); Igen, több ilyen történt (3); Igen, nagyon sok ilyen történt (4); Nem tudok, nem kívánok válaszolni a kérdésre (99)”.
} 


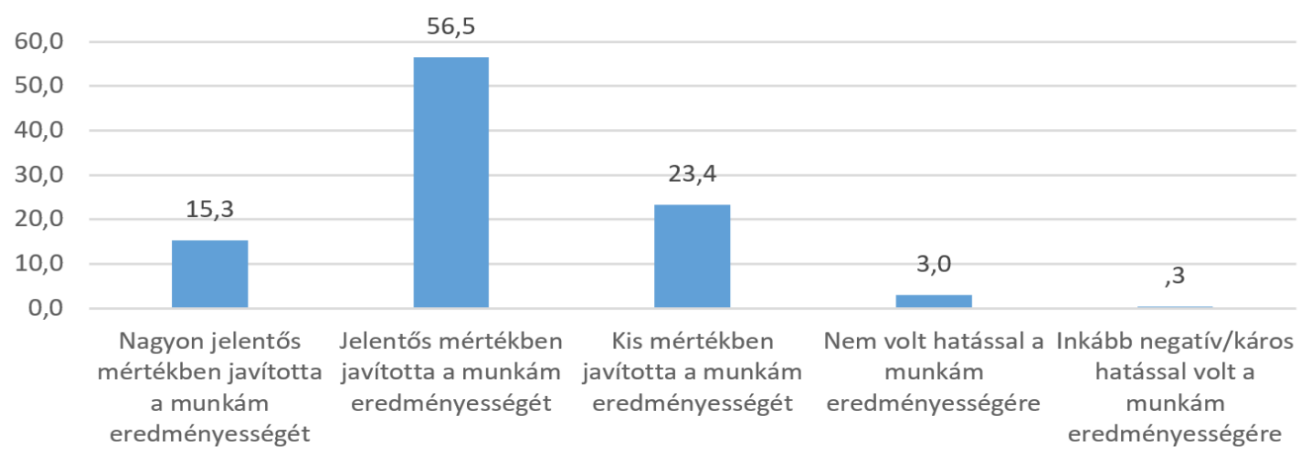

3. ábra: A pedagógusok vélekedése az általuk kiválasztott újítás nyomán kialakuló új gyakorlatuk eredményességéről (\%) $(\mathrm{N}=1307)^{12}$

Bár nem eredményességet vizsgál, de értelmezhető egyfajta beválásra irányuló információgyưjtésként az a kérdés is, amely a kidolgozott innovációk terjedését tárja fel. A kérdőív arra kérte a válaszadókat, jelöljék meg, történt-e kezdeményezés arra, hogy a kiválasztott újítást vagy annak jelentősebb elemeit más intézményeknek, szervezeti egységeknek átadják. A válaszlehetőségek nemcsak annak megjelölésére adtak lehetőséget, hogy történt-e erre vonatkozóan próbálkozás, hanem arra is, hogy más, belföldi vagy külföldi intézmények átvették-e a gyakorlatot. A válaszok alapján a megnevezett újítások $22 \%$-a terjedt belföldön, $1 \%$-a (összesen 11 eset) pedig külföldre is eljutott.

Az Innova kutatás igyekezett feltárni, hogy a pedagógustanulásként értelmezett pedagógiai innovációs tevékenységek milyen tanulási mintázatok, illetve milyen ezt alakító tényezők mellett valósulnak meg. A kutatás az olyan általános, a tanulási folyamatokra is feltételezhetően hatással lévő héttérváltozók, mint a kvalifikáció ${ }^{13}$ vagy az idegennyelv ismeret mellett ${ }^{14}$ számos olyan változó mérésére is vállalkozott, amely a tanulási mintázatokhoz, illetve az azt formáló elemekhez (lásd például motivációk, tanulási tevékenységek), a tanulás kontextuális feltételeihez (lásd például a tanulás szervezeti és rendszerszintű támogatása) kapcsolható.

Az egyik legfontosabb kapcsolódó problémakör, hogy a pedagógusok tanulása milyen mértékủ kognitív és affektív váltásokat tesz szükségessé, illetve tacit tu-

${ }^{12}$ Feltett kérdés: Hogyan hatott az Ön munkájának eredményességére a kiválasztott újítás?

${ }^{13}$ „A végzettségekre, kvalifikációkra irányuló kérdés eredményei szerint [...] a kitöltők nagy része rendelkezik pedagógiai végzettséggel (3038 eset), valamint főiskolai szintű vagy BA diplomával (3287 eset). Emellett viszonylag sokan rendelkeznek egyetemi végzettséggel (1489 eset), vezetőképzésben szerzett végzettséggel (1060 eset), illetve egyéb pedagógusi szakvizsgával (959)." (Nagy-Rádli - Szarka-Bögös, 2019).

${ }^{14} \mathrm{~A}$ válaszadók 64\%-a jelezte, hogy olvas és kommunikál idegen nyelven. 
dást eredményező tanulási folyamatok esetében mennyire tekinthetők újnak vagy a korábbi gyakorlattól eltérőnek az elsajátítandó gyakorlatok. Az Innova kutatás keretein belül e kérdés úgy fogalmazódott meg, hogy a válaszadók által kiválasztott konkrét innovációk, újítások mennyire tértek el a korábbi gyakorlattól, azaz annak megvalósítása mekkora változtatást igényelt a pedagógustól. A kapcsolódó kérdésnél ${ }^{15}$ a válaszadók 14\%-a jelezte, hogy kialakult gyakorlata nagyon jelentős mértékben különbözött a korábbitól, ők olyan csoportot alkotnak, akiktől feltételezhetően különösen intenzív tanulást igényelt az általuk megjelölt innováció. A válaszadók 58\%-a jelölte, hogy az újítás nyomán jelentősebb mértékben eltér gyakorlatuk a korábbitól, róluk szintén feltételezhetjük, hogy komolyabb, kihívásokkal teli tanulási folyamaton kellett átmenniük az újítás bevezetése során. A kérdőívet visszaküldők egy csekélyebb hányada, 25\%-a jelezte, hogy az új gyakorlat minimális mértékben eltérő, míg a válaszadó pedagógusok 3\%-a nem jelzett differenciát. Számolnunk kell azzal, hogy az utóbbi két válasz mögött meghúzódhat az, hogy a bevezetett változtatás nem vagy alig különbözött a korábbi gyakorlattól, illetve az is, hogy egy jelentős változtatást igénylő újítás kudarcos megvalósítása nyomán a pedagógiai gyakorlatban nem következett be számottevő változás.

A munkahelyi tanulásáról való mai tudásunknak megfelelően a kutatás kiemelt figyelmet fordított a tanulás tartalmi területére, ezen belül többek között az osztálytermi, extrakurrikuláris, szervezeti és a technológiai igénnyel bíró újítások megjelenésére. A vizsgált területek kiterjedtek a foglalkozások, tanórák során alkalmazott módszerekre és eszközökre, a tanulói, hallgatói teljesítmények értékelésére, mérésére, a foglalkozásokon vagy tanórákon kívüli tevékenységekre, a technikai eszközök nevelésben, oktatásban, képzésben történő használatára, a szervezet belső müködésére, a szervezet müködésével, vezetésével kapcsolatos technikákra, a partnerekkel, igénybevevőkkel való kapcsolatokra, a tanulók (hallgatók, gondozottak) kompetenciáinak, képességeinek eredményesebb fejlesztésére, a tehetségesek gondozására, a hátrányos helyzetűek, leszakadók oktatására, nevelésére (lásd 4. ábra).

\footnotetext{
${ }^{15}$ Feltett kérdés: Hogyan ítéli meg: Önnek a kiválasztott újítás nyomán kialakult gyakorlata mennyire tér el a korábbi gyakorlatától? Válaszlehetőségek: Egyáltalán nem tér el, Minimális mértékben eltér, Jelentősebb mértékben eltér, Nagyon jelentős mértékben eltér.
} 


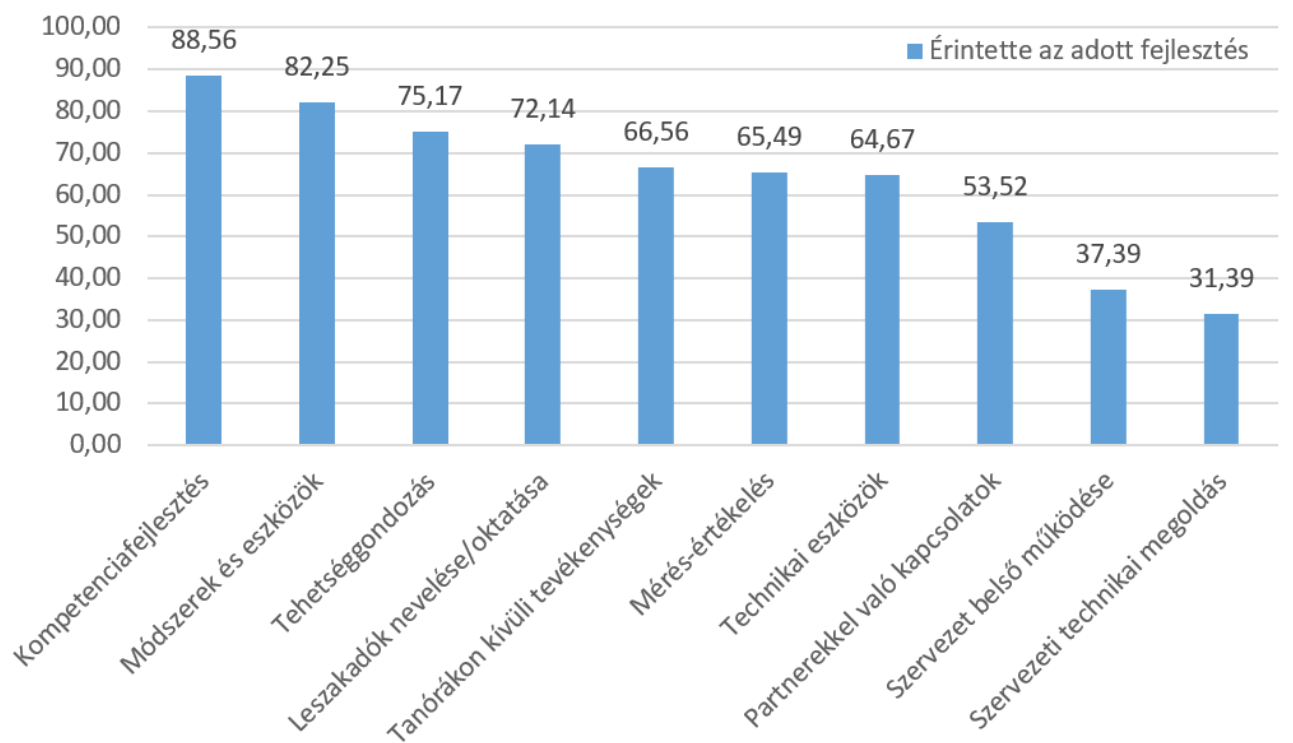

4. ábra: A kiválasztott újítás által érintett területetek (\%) (N=469-1334)

A válaszadó pedagógusok leggyakrabban olyan újítást jelöltek meg, amelyek érintették a tanulók kompetenciáinak, képességeinek eredményesebb fejlesztését (88\%), a tanórákon alkalmazott módszereket és eszközöket (82\%). Legkevésbé gyakran a szervezeti mủködéssel, illetve annak technológiai támogatásával kapcsolatos újításokra esett a választás. A pedagógusok 38\% és 32\%-a jelölte, hogy az általa kiválasztott innováció érintette ezeket a területeket. Érdemes itt megjegyezni, hogy a szervezeti folyamatokat érintő innovációk kidolgozása és megvalósítása a szakmai fejlődés egy olyan sajátos formáját adja, amely gyakran másoknál jobban igényli a munkahelyi tanulás egyik kulcstényezőjeként azonosított „határátlépésekkel" (boundary crossing) ${ }^{16}$ történő tanulást és belső tudásmegosztást, a környezet aktív monitorozását, az alkalmazott pedagógiai gyakorlatok rendszerszintű elemzését. A kutatás vizsgálta az innovációkat elindító motivációs tényezőket is oly módon, hogy a kérdőívben kérte a válaszadókat, hogy meghatározott motivációs elemekről jelöljék, volt-e szerepe és ha igen mekkora a kiválasztott innováció elindításában. ${ }^{17} \mathrm{~A}$ válaszok alapján azt gondolhatjuk, hogy az innovációk

${ }^{16}$ Lásd: Tsui - Law, 2007; Schnellbach, 2014.

${ }^{17}$ Feltett kérdés: Az újítások keletkezésében sokféle tényezőnek lehet szerepe. Kérjük, jelölje meg, hogy az alábbiak közül melyeknek volt szerepe az Ön által kiválasztott újítás létrejöttében! Több sorban is bejelölheti az „igen” válaszlehetőséget. Kérjük, hogy mindegyik sorban jelöljön választ! Megjelölt motivációs elemek: Valamilyen problémára (...) kerestem megoldást; Külső ösztönzésre vagy elvárásra (...) 
csak nagyon kis csoportja keletkezhetett nem szándékolt, véletlen módon (5\% jelezte, hogy ennek volt szerepe, 9\% pedig, hogy rendkívül nagy szerepe volt). A leggyakrabban valamilyen problémára (például a tanulói összetétel változása, tanulási nehézségek, motiválási problémák, tanulmányi eredmények romlása stb.) kerestek megoldást a válaszadó pedagógusok (47\% jelezte, hogy ennek volt szerepe, 29\% pedig, hogy rendkívül nagy szerepe volt) Emellett - az Innova adatbázis alapján - inspiráló hatással lehettek a más kollégák, intézmények/szervezetek sikeres gyakorlatai (41\% jelezte, hogy ennek volt szerepe, 5\% pedig, hogy rendkívül nagy szerepe volt), a továbbképzések (30\% jelezte, hogy ennek volt szerepe, $11 \%$ pedig, hogy rendkívül nagy szerepe volt), az adott megoldás iránt elkötelezett szakmai közösségek is (16\% jelezte, hogy ennek volt szerepe, $2 \%$ pedig, hogy rendkívül nagy szerepe volt).

A tanulási motiváció egy fontos aspektusát adja a külső ösztönzések és elvárások szerepe. Az Innova adatok szerint a válaszadók egy jól meghatározható csoportjánál ezek jelentős hatással voltak a megjelölt újítások elindítására. Ezen belül a kérdőív két típusú motivációs csoportot különböztetett meg: az olyan külső hatásokat, amelyek például a központi szabályozás változásához, uniós fejlesztési programokban való részvételhez, fenntartói igényhez vagy partnerek igényeihez kapcsolódnak (33\% jelezte, hogy ennek volt szerepe, $8 \%$ pedig, hogy rendkívül nagy szerepe volt) és az olyanokat, amelyek a vezetői ösztönzéshez, a vezetés felől érkező nyomáshoz kötődnek (27\% jelezte, hogy ennek volt szerepe, 10\% pedig, hogy rendkívül nagy szerepe volt). Érdemes itt megemlíteni: a külső ösztönzésre vagy nyomásra kapcsolódók körében is egy jól megragadható csoport jelölte, hogy vonzónak találta az újításhoz kapcsolódó szakmai megközelítést (a teljes minta $51 \%$ jelezte, hogy ennek volt szerepe, $23 \%$ pedig, hogy rendkívül nagy szerepe volt).

Az innovációk megvalósításához kapcsolódó tanári tanulás egyik fontos aspektusát a adhatja tanulás fennmaradó vagy lezáruló jellege: az a kérdés, hogy a kikísérletezett új gyakorlatokat az első beválás után a pedagógusok késznek tekintetik-e, vagy hosszabb távon is formálják, felülvizsgálják, alakítják azt. Az Innova kutatás kérdései közül e problémához a legközelebb az áll, amely azt próbálta mérni, hogy a keletkezést követően mennyire változott a kiválasztott újítás. A vá-

történt az újítás; Más kollégák, intézmények/szervezetek sikeres gyakorlata inspirálta az újítást; Továbbképzésen ismertem meg korábban általam nem alkalmazott új megoldásokat; Az újításhoz kapcsolódó szakmai megközelítést találtam vonzónak; Az adott megoldás iránt elkötelezett szakmai közösség (...) tagja lettem; Nem szándékolt, véletlen módon keletkezett az újítás; Nem, ennek nem volt szerepe / Igen, ennek volt szerepe / Ennek rendkívül nagy szerepe volt. 
laszadók $21 \%$-a jelölte, hogy nem változott, ma is úgy alkalmazza, mint eredetileg, 66\%-a szerint az újítás a keletkezése óta kismértékben módosult, és $13 \%$ jelölte azt, hogy nagymértékben módosult. Ez persze nem független attól, hogy a válaszadást megelőzően mikor keletkezett, és mennyi ideig alkalmazták a kiválasztott innovációt. Az erre irányuló kérdés alapján azt gondolhatjuk, hogy a válaszadók döntő többsége (85\%) a kitöltés időpontjában alkalmazta a kiválasztott innovációt, a legtöbb 5 évnél régebben keletkezett (38\%), de magas volt azok aránya is, amelyek 35 évvel korábban jöttek létre $(33,8 \%)$. 
Az újításra hatással lévő tényezőkről a kérdőív egyéb formákban is tájékozódott. Így vizsgálta a szakmai támogatással, a munkahelyi környezettel, a változó feltételekkel vagy a kísérletezés természetével kapcsolatos tényezőket és ezek hatását is. E tényezők mindegyikéről úgy gondolkodhatunk, mint amik az innovációk mögötti tanulási folyamatok meghatározásán keresztül lehetnek leginkább képesek hatást gyakorlolni az új megoldások kidolgozására. A kapcsolódó kérdés arra kérte a válaszadókat, hogy becsüljék meg, az adott tényező jelenlétét tapasztalták-e, és ha igen, volt-e érdemleges hatása (anélkül, hogy jelölte volna, hogy e tényezők segítő vagy gátló hatását méri). ${ }^{18} \mathrm{~A}$ legerősebb hatást a saját intézményen belüli kollégákkal folytatott beszélgetések, viták kapcsán jelölték a válaszadók: $42 \%$-uk jelölte, hogy tapasztalt ilyet, és ennek volt érdemleges hatása a megjelölt innovációra. Szintén erősen érzékeltette hatását a válaszadók szerint a szervezeten kívülről kapott szakmai támogatás (30\%), illetve a megoldandó feladatok bonyolultsága (27\%) az innovációk megvalósításában. Külön figyelmet igényel az, hogy az általánosan a fejlesztő tevékenységet gátló tényezőként azonosított elemek, bár jelen voltak a megjelölt újítások megvalósítása során, kevésbé voltak meghatározóak a válaszadók szerint. Így például a pedagógusok $62 \%$-a jelezte, hogy tapasztalt időhiányt, időnyomást, de csak 21\%-uk szerint volt ennek érzékelhető hatása az innováció megvalósítására. Hasonlóképpen, a válaszadók fele (52\%) érzékelte az anyagi erőforrások vagy a szükséges technikai eszközök hiányát, de csak 19\% jelezte ennek jelentős szerepét. A válaszadók közel fele számolt be az érintettek, résztvevők kicserélődéséről (48\%), a szervezeten belüli viszonyokról, azok megváltozásáról (44\%), az új megoldások kockázatáról (42\%), harmada pedig a sikertelennek bizonyuló próbálkozásokról (31\%), de jellemzően csupán egy szűkebb kör (sorrendben a vizsgált sokaság 13\%, 17\%, 10\% és 7\%-a) szerint bírtak e tényezők érzékelhető hatással. Érdemes itt megjegyezni, hogy a gyüjtött adatok alapján a vizsgált mintán kevésbé volt általánosan jellemző a vezetés támogatásának hiánya ( $14 \%$ jelezte a problémát, és $5 \%$ szerint volt hatása).

A kiválasztott innováció megvalósulásának feltárása emellett kiterjedt annak vizsgálatára is, hogy mely alrendszerhez kapcsolódik, illetve hazai vagy külföldi kollégák/szervezetek tapasztalatai segítették-e a kiválasztott innovációt. Bár itt 5\% alatti a külföldi, illetve a felsőoktatási intézmények tapasztalatainak felhasználá-

\footnotetext{
${ }^{18}$ Feltett kérdés: „Az újítások keletkezésében sokféle tényezőnek lehet szerepe. Kérjük, jelölje meg, hogy az alábbiak közül melyeknek volt szerepe az Ön által kiválasztott újitás létrejöttében! Több sorban is bejelölheti az „igen” válaszlehetőséget. Kérjük, hogy mindegyik sorban jelöljön választ! Nem, ennek nem volt szerepe (1); Igen, ennek volt szerepe (2); Ennek rendkívül nagy szerepe volt (3); Nem tudok, nem kívánok válaszolni (99)".
} 
sát jelölők aránya, az egyetem-iskola együttműködések jelentősége, illetve a jó gyakorlatok importálása olyan fontos problémakör a tanári tanulás kapcsán, amelyek indokolhatják az ezek vizsgálatára alkalmas esetek mély, önálló elemzését.

Az Innova kutatás adatbázisainak teljes feldolgozása e tanulmány születésekor még nem állt rendelkezésre, ami megnehezíti az adatbázis mély, összefüggések feltárására alkalmas másodelemzését. Mindazonáltal az elsődleges változók közötti kapcsolatok, illetve egy elméleti alapon létrehozott, az innovációk komolyságát mutató változó és annak más - primér - változókkal való együttjárása már mutat valamilyen képet a pedagógusok szakmai fejlődéséről.

Az elsődleges változók összefüggéseinek vizsgálatánál azt a kérdést vettük alapul, amely arról gyüjtött információt, vajon a kiválasztott újítás a válaszadó meglátása szerint milyen mértékben javította munkájának eredményességét. ${ }^{19}$ Azok a pedagógusok, akik szerint a megjelölt innováció nagyon jelentős mértékben segítette munkájuk eredményességét leggyakrabban nevelési-oktatási feladatokhoz szorosan kapcsolódó innovációs területeket jelöltek meg. Olyan innovációkról számoltak be, amelyek érintették a tanulók kompetenciáinak fejlesztését (90,9\%), az alkalmazott módszereket és eszközöket (86\%), a leszakadók oktatását (79,4\%), a tehetséggondozást (79,3\%), a tanulói, teljesítmények mérését (71,2\%), a technikai eszközök használatát (69\%), az extrakurrikuláris tevékenységeket $(67,4 \%)$ és a partnerekkel való kapcsolatokat $(63,9 \%)$. Az eredményes innovációkként jelölt új gyakorlatok közül legkevésbé gyakoriak a szervezet belső müködését $(44,5 \%)$ és a szervezet működésével kapcsolatos technikákat érintő innovációk (34,5\%) voltak. ${ }^{20}$

A kevéssé eredményesnek gondolt innovációkat létrehozók körét is bevonó azaz a teljes mintán végzett - elemzések azt mutatják, hogy a legkevésbé az extrakurrikuláris foglalkozások szervezése $(\mathrm{p} \geq 0,046)$ és a technikai eszközök alkalmazása $(\mathrm{p} \geq 0,067)$ jelenthet olyan tartalmi területet, amelyek (vagy amelyeket jellemzően meghatározó tényezők) kapcsolódhatnak a változtatások sikerességének vagy sikertelenségének érzetéhez. A többi tartalmi terület érintettsége esetében olyan kapcsolatokat találtunk $(\mathrm{p} \leq 0,007)$, amelyek nyomán már feltételezhető,

\footnotetext{
${ }^{19}$ Feletett kérdés: „Hogyan hatott az Ön munkájának eredményességére a kiválasztott újítás?” Válaszlehetőségek: „Nagyon jelentős mértékben javította a munkám eredményességét”, „Jelentős mértékben javította a munkám eredményességét”, „Kis mértékben javította a munkám eredményességét”, „Nem volt hatással a munkám eredményességére”, „Inkább negatív/káros hatással volt a munkám eredményességére”, „Nem tudok, nem kívánok válaszolni”, „Egyéb, éspedig:”

${ }^{20}$ Lásd például elektronikus nyilvántartások, belső levelezés, vezetői információs rendszer, e-napló.
} 
hogy az itt zajló munka bizonyos elemei a pedagógusok tanulásának kedvező feltételeket biztosítanak (5. táblázat).

\begin{tabular}{|c|c|c|c|c|c|c|c|c|}
\hline \multicolumn{9}{|c|}{$\begin{array}{l}\text { Hogyan hatott az Ön munkájának eredményességére a kiválasztott újitás, illetve ennek } \\
\text { nyomán kialakult új gya korlat? }\end{array}$} \\
\hline & \multirow{2}{*}{$\begin{array}{l}\text { Érintette a } \\
\text { kiválasztott } \\
\text { újítás }\end{array}$} & \multirow{2}{*}{$\mathrm{N}$} & \multirow{2}{*}{ M } & \multirow{2}{*}{$\mathrm{t}$} & \multirow{2}{*}{ df } & \multirow{2}{*}{$\mathrm{p}$} & \multicolumn{2}{|c|}{$95 \% \mathrm{Cl}$} \\
\hline & & & & & & & Alsó & Felsô \\
\hline \multirow{2}{*}{$\begin{array}{l}\text { A foglalkozások, tanórák } \\
\text { tervezéséhez és } \\
\text { megvalósításához } \\
\text { kapcsolódó módszerek és } \\
\text { eszközök }\end{array}$} & Nem & 228 & 2,46 & \multirow{2}{*}{4,412} & \multirow{2}{*}{1297} & \multirow{2}{*}{, 000} & \multirow{2}{*}{154} & \multirow{2}{*}{, 401 } \\
\hline & Igen & 1071 & 2,18 & & & & & \\
\hline \multirow{2}{*}{$\begin{array}{c}\text { A tanulói, hallgatói } \\
\text { teljesítmények értékelése } \\
\text { vagy mérése }\end{array}$} & Nem & 442 & 2,36 & \multirow{2}{*}{3,698} & \multirow[b]{2}{*}{1291} & \multirow[b]{2}{*}{000} & \multirow[b]{2}{*}{088} & \multirow[b]{2}{*}{286} \\
\hline & Igen & 851 & 2,17 & & & & & \\
\hline \multirow{2}{*}{$\begin{array}{l}\text { A foglalkozásokon vagy } \\
\text { tanórákon kívüli } \\
\text { tevékenységek }\end{array}$} & Nem & 432 & 2,30 & \multirow{2}{*}{1,988} & \multirow{2}{*}{1284} & \multirow{2}{*}{047} & \multirow{2}{*}{001} & \multirow{2}{*}{,202 } \\
\hline & Igen & 854 & 2,20 & & & & & \\
\hline \multirow{2}{*}{$\begin{array}{c}\text { Technikai eszközök } \\
\text { nevelésben, oktatásban, } \\
\text { képzésben történő } \\
\text { használata }\end{array}$} & Nem & 455 & 2,29 & \multirow[b]{2}{*}{1,827} & \multirow[b]{2}{*}{1285} & \multirow[b]{2}{*}{,068 } & \multirow[b]{2}{*}{,- 007} & \multirow[b]{2}{*}{ 192 } \\
\hline & Igen & 832 & 2,20 & & & & & \\
\hline \multirow{2}{*}{$\begin{array}{l}\text { Szervezet múködésével, } \\
\text { vezetésével kapcsolatos } \\
\text { technikák }\end{array}$} & Nem & 794 & 2,30 & \multirow{2}{*}{3,540} & \multirow{2}{*}{1278} & \multirow{2}{*}{000} & 070 & 274 \\
\hline & Igen & 486 & 2,12 & & & & , 0/9 &, $2 / 4$ \\
\hline A tanulók kompetenciáinak, & Nem & 879 & 2,28 & & & & & \\
\hline $\begin{array}{l}\text { képességeinek } \\
\text { eredményesebb fejlesztése }\end{array}$ & Igen & 404 & 2,14 & 2,686 & 1281 & ,007 & 038, & 243, \\
\hline A hátrányos helyzetüek, & Nem & 603 & 2,34 & 4.587 & 1279 & 000 & 127 & 316 \\
\hline $\begin{array}{c}\text { Ieszakadok } \\
\text { oktatása/nevelése }\end{array}$ & Igen & 678 & 2,12 & & & & & \\
\hline
\end{tabular}

5. táblázat: Az innováció eredményességének érzetét mérő változó és az innováció által érintett területek (statisztikai elemzés adattábla)

Azok, akik azt jelölték, hogy „nagyon jelentős mértékben javította” munkájuk eredményességét a kiválasztott újítás, két ösztönző kiemelt szerepéről számoltak be: az első helyen a valamilyen problémára (például a tanulói összetétel változása, tanulási nehézségek, motiválási problémák, tanulmányi eredmények romlása stb.) való megoldás keresése $(45,2 \%)$, míg a második helyen az újításhoz kapcsolódó szakmai megközelítés vonzósága (43,2\%) állt. Az innovációjuk eredményességét leginkább pozitívan megítélő válaszadók a további ösztönzők intenzív jelenlétét csak sokkal szűkebb arányban jelölték meg: így a harmadik helyen álló motivációs tényező, a továbbképzésen megismert új megoldások kapcsán a csoporton belül a válaszadók 19,8\%-a jelöle csupán, hogy „ennek rendkívül nagy szerepe volt”. Az innovációikat kevésbé eredményesnek gondoló pedagógusok körét is bevonó - azaz a teljes mintán végzett - elemzések alapján is azt látjuk, hogy e három ösz- 
tönzőkategória bírhat meghatározó súllyal $(\mathrm{p} \leq 0,03)$ az innovációkkal kapcsolatos eredményességérzet terén.

Az innovációk komolyságát mérő összetett változó a fent alkalmazott, az eredményességre irányuló kérdés mellett további hármat is magában foglal: egy az innováció alkalmazására vagy elhalására, egy az innováció terjedésére és egy az innováció változására vonatkozó kérdést. E négy item ad lehetőséget arra, hogy megragadhatóak legyenek azok a komolynak gondolt innovációk, amelyek képesek hozzájárulni alkalmazóik munkájának eredményességéhez, vagy eredményességérzetéhez, amelyek régóta életképesek, amelyek idővel formálódnak, képesek megújulni, és nem zárulnak le a kezdeti kísérletezések után, illetve amelyek képesek terjedni, más közegekben is meggyökerezni (5. ábra).

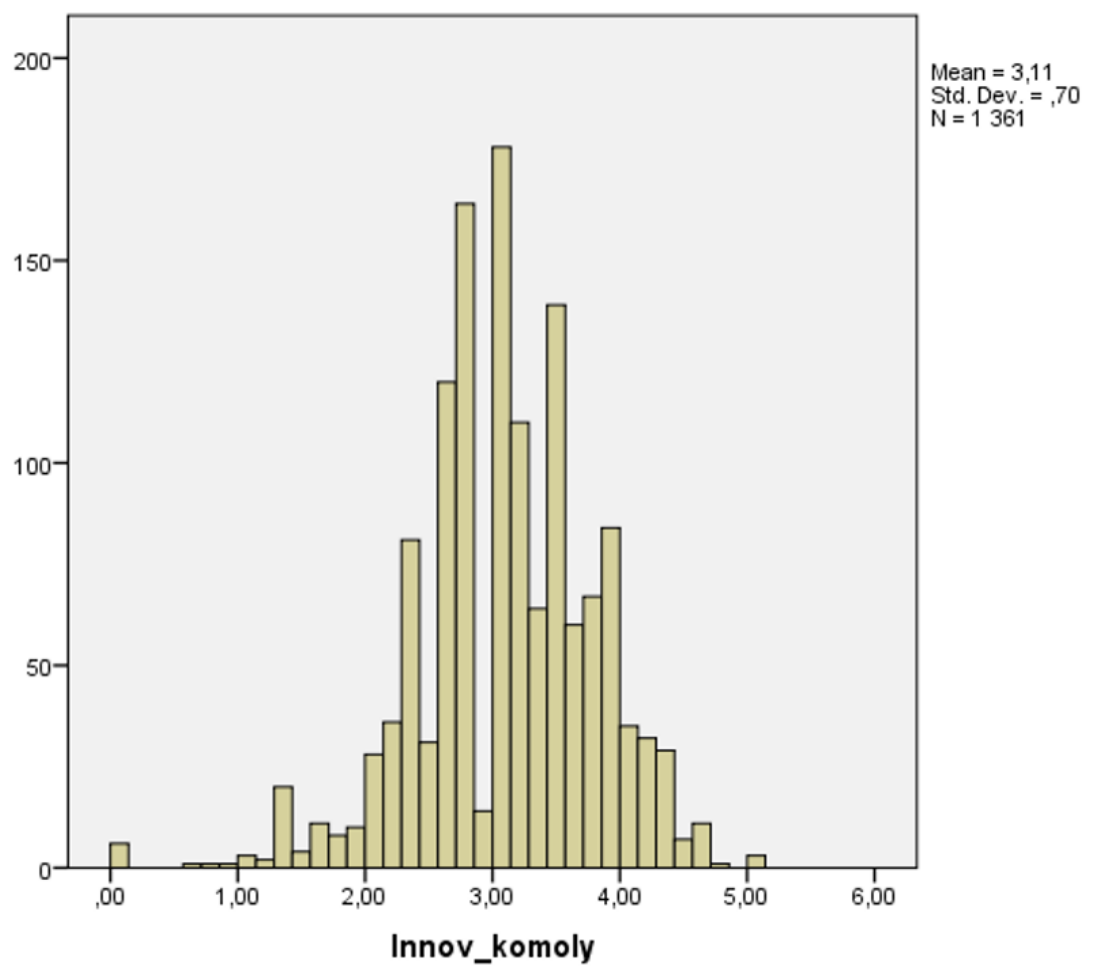


Pedagógusképzés • 18(46), 2019/3-4.

\begin{tabular}{|c|c|}
\hline \multirow{5}{*}{$\begin{array}{l}\text { Hogyan hatott az Ön munkájának } \\
\text { eredményességére a kiválasztott újítás? }\end{array}$} & Nagyon jelentős mértékben javította a munkám eredményességét \\
\hline & Jelentős mértékben javította a munkám eredményességét \\
\hline & Kis mértékben javította a munkám eredményességét \\
\hline & Nem volt hatással a munkám eredményességére \\
\hline & Inkább negatív/káros hatással volt a munkám eredményességére \\
\hline \multirow{5}{*}{$\begin{array}{l}\text { Mennyi ideig alkalmazta a kiválasztott } \\
\text { újítást? }\end{array}$} & $\begin{array}{l}2 \text { évig vagy annál rövidebb ideig alkalmaztam, de már nem } \\
\text { alkalmazom }\end{array}$ \\
\hline & 3-5 évig alkalmaztam, de már nem alkalmazom \\
\hline & Több mint 5 évig alkalmaztam, de már nem alkalmazom \\
\hline & Jelenleg is alkalmazom, mint új gyakorlatot \\
\hline & Jelenleg is alkalmazom, de már a mindennapi gyakorlat részévé vált \\
\hline \multirow{3}{*}{$\begin{array}{l}\text { A keletkezését követően mennyire } \\
\text { változott a kiválasztott újítás? }\end{array}$} & Nem változott (ma is úgy alkalmazom, mint eredetileg) \\
\hline & Az újítás a keletkezése óta kismértékben módosult \\
\hline & Az újítás keletkezése óta nagymértékben módosult \\
\hline \multirow{4}{*}{$\begin{array}{l}\text { Történt-e kezdeményezés arra, hogy a } \\
\text { kiválasztott újítást vagy annak } \\
\text { jelentősebb elemeit más } \\
\text { intézményeknek, szervezeti } \\
\text { egységeknek átadja/átadják. }\end{array}$} & Igen, de nem tudok arról, mások átvették-e \\
\hline & Igen, és tudok róla, hogy mások átvették belföldön \\
\hline & Igen, és tudok róla, hogy mások átvették külföldön \\
\hline & Nem történt ilyen próbálkozás \\
\hline
\end{tabular}

5. ábra: Az innováció komolyságát mérő kompozitmutató (InKom) eloszlásfüggvénye és összetevői

A létrehozott kompozit változó elemzése alapján azt láthatjuk, hogy a szakmai újítások magas „komolysági” szintje jellemzően együtt jár a megvalósító pedagógusok tagságával legalább egy olyan szakmai szervezeten belül (például egyesület, szakmai testület, szakértői bizottság), amelynek tevékenysége közvetlenül kapcsolódik mindennapos munkavégzéséhez. Azok esetében, akik legalább egy ilyennek tagjai, szignifikánsan magasabb értékủ $(\mathrm{p} \leq 0,001)$ lett az általuk megjelölt innováció komolyságát mérő kompozit mutató. Emellett többek között meghatározónak tűnik a fejlesztési gyakorlat, a tudatos fejelsztési tevékenység is: az adatok azt mutatják, hogy azokhoz kapcsolódnak inkább „komoly” innovációk, akik jelezték, hogy az általuk kidolgozott, vagy részvételükkel zajlott fejlesztésekről a kérdőív kitöltését megelőző tíz évben dokumentálás vagy másokkal történő megosztás céljából leírás készült. Az adatok szerint a korábbi fejlesztési gyakorlat egy speciális területe, a külső fejlesztések megvalósítása - illetve az ott zajló speciális tanulási folyamatok - is komoly hatással lehetnek az egyes innovációk megvalósítására. Azokhoz a válaszadókhoz, akik jelölték, hogy a kitöltést megelőző 10 évben részt vettek olyan fejlesztési programban, projektben, amelyre az intézményük külső támogatást kapott és amelyben a korábbitól eltérő tananyagot, taneszközt, pedagógiai módszereket kellett alkalmazni $(\mathrm{p} \leq 0,011)$, új tananyagot, taneszközt, pedagógiai módszereket kellett létrehozni $(\mathrm{p} \leq 0,001)$, illetve amelyben képzéseken kellett részt venni $(\mathrm{p} \leq 0,008)$, szignifikánsan magasabb InKom értékek kapcsolód- 
tak, mint akik nem jelöltek ilyen típusú fejlesztési tevékenységeket. Az egyes programtípusokban való resztével gyakoriságának növekedésével együtt nő az egyes mutatók InKom változóval való kapcsolatának erőssége is.

A számos elemzési lehetőség közül talán érdemes itt kiemelni, hogy a kérdőív a pedagógusok tanulásának klasszikus akadályait több kérdésben is felsorakoztatja. Így lehetőség nyílik feltárni, hogy az olyan gátló tényezők, mint az időhiány, a kedvezőtlen központi szabályozás, a szegényes infrastruktúra vagy éppen a munkahely humán feltételeiből fakadó problémák megjelenése miként kapcsolódik a komoly innovációk megvalósításához (InKom). A MoTel kutatás számára végzett elemzések azt mutatják, hogy ezek erős jelenléte nem jár együtt a pedagógusok innovatív megoldásainak alacsony „komolysági” szintjével. Sőt, az adatok szerint azokhoz kapcsolódnak a legmagasabb InKom átlagok, akik azt jelölték, hogy eredményes munkájukat folyamatosan, illetve nagyon nagy mértékben akadályozták a fenti tényezők, így például az országos szintű szabályok rugalmatlansága (6. ábra).

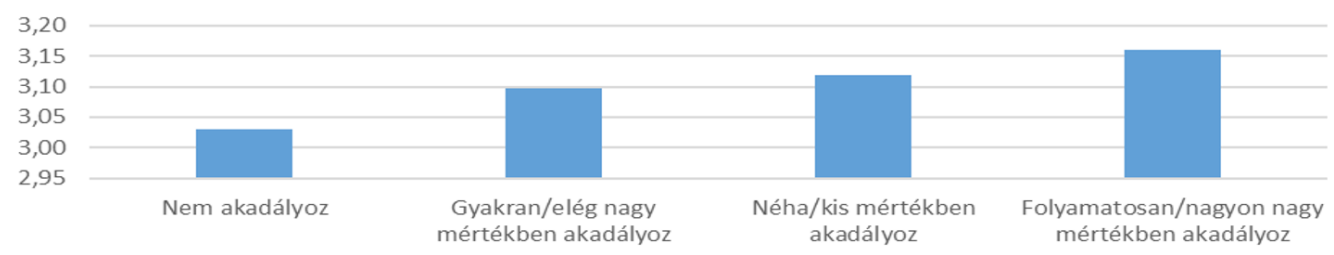

6. ábra: InKom átlag az országos szintű szabályok rugalmatlanságának akadályozó jellege szerint

$(\mathrm{N}=163-539)$

\section{Összegzés}

Az Innova kutatás másodelemzése elsődlegesen a pedagógusok újító magatartásáról való tudásunkat mélyítette tovább. A kutatási eredmények alapján az újítások keletkezésének és terjedésének fontos forrása a más kollégák vagy intézmények inspiráló gyakorlata, a különböző szakmai hálózatokban való részvétel, a fejlesztési programokba való bekapcsolódás, illetve a konkrét munkahelyi/szakmai probléma megoldásának igénye. Ezek olyan tényezők lehetnek, amelyek újításokra, kísérletezésre ösztönzik a pedagógusokat és az intézményeket, ezáltal erősítik az érintettek tanulását, méghozzá munkába ágyazott módon. Ezzel összefüggésben a kutatás megerősítette a munkatársak újításokra való nyitottságának mint olyan attitűdnek a fontosságát, amely hozzájárult a helyi szintű újítások keletkezéséhez, terjedéséhez és az ezen folyamatokhoz kapcsolódó tanuláshoz. Bár e kutatás másodelemzése nyomán is azt látjuk, hogy fontos szerephez jut a legtöbb olyan tényező, amely a külső beavatkozások megvalósítása közben kialakuló 
szakmai fejlődést meghatározza, tapasztalhatók eltérések is. Így például a motivációs bázis esetében láthatjuk, hogy a saját innovációk esetében a problémaorientált jelleg kerül előtérbe. A másodelemzés eredménye továbbá arra is rámutat, hogy a fejlesztő tevékenységek általános gátjaként azonosított olyan elemek, mint az időhiány, a szegényes infrastruktúra, vagy a kedvezőtlen szabályozási környezet, az adatok szerint kevéssé érzékeltetik hatásukat a helyi szintủ innovációk sajátosságaiban. E kutatás is igazolja, hogy a különböző fejlesztési programok fontos katalizátor szerepet tölthetnek be a pedagógusok folyamatos szakmai fejlődése szempontjából, kifejezetten azok a kezdeményezések, ahol a pedagógusoknak maguknak kell valamilyen tananyagot, taneszközt vagy pedagógiai módszert létrehozni.

\section{Irodalom}

Anka Á. - Baráth T. - Cseh Gy. - Fazekas Á. - Horváth L. - Kézy Zs. - Menyhárt A. - Sipos J. (2016): Dél-alföld megújuló iskolái. SZTE, Szeged.

Bakkenes, I. - Vermunt, J. - Wubbels, T. (2010): Teacher learning in the context of educational innovation: Learning activities and learning outcomes of experienced teachers. Learning and Instruction, 20. évf., 533-548.

Barnett, J. - Hodson, D. (2001): Pedagogical context knowledge: Toward a fuller understanding of what good science teachers know. Science Education, 84. évf., 426-453.

Boekaerts, M. (2010): The crucial role of motivation and emotion in classroom learning. In: Dumont, H., Istance, D. és Benavides, F. (szerk.): The nature of learning (Using research to inspire practice). OECD, Paris.

Bullock, S. M. (2011): Inside Teacher Education, Challenging Prior Views of Teaching and Learning. Sense Publishers, Rotterdam.

Cohen, D. K. - Hill, H. C. (2001): Learning policy: When state education reform works. Yale University Press, New Haven.

Darling-Hammond, L. (1990): The Power of the Bottom over the Top. Educational Evaluation and Policy Analysis, 3. évf., 339-347.

Darsø, L. - Høyrup, S. (2012): Developing a Framework for Innovation and Learning in the Workplace. In: Melkas, H. és Harmaakorpi, V. (szerk.). Practice-Based Innovation: Insights, Applications and Policy Implications. Springer, London. 135-154

DuFour, R. (2004): What is a „Professional Learning Community"? Educational Leadership, 8. évf., 6-11. 
DuFour, R. - DuFour, R. - Eaker, R. - \& Many, T. (2006): Learning by Doing. A Handbook for Professional Learning Communities at Work. Solution Tree Press, Bloomington.

Falus I. (2001). Pedagógus mesterség - pedagógiai tudás. Iskolakultúra, 2. évf., 2128.

Fazekas Á. (2016): A közoktatás-fejlesztési beavatkozások hatásmechanizmusai jelentés az empirikus adatfelvételről. ELTE PPK, Kézirat.

Fazekas Á. (2018): A közoktatás-fejlesztési beavatkozások hatásmechanizmusai. ELTE PPK, Kézirat.

Fazekas Á. (2018): A közoktatás-fejlesztési beavatkozások hatásmechanizmusai. Doktori értekezés. ELTE PPK, Kézirat.

Fazekas Á. - Horváth L. (2019): Pedagógusok folyamatos szakmai fejlödése másodelemzések alapján. ELTE PPK, Kézirat.

Fazekas Á. - Halász G. - Horváth L. - Sági M. (2018): Az oktatási innovációs folyamatok elemzése meglévő adatbázisok másodelemzésével. ELTE PPK, Kézirat.

Fazekas Á. - Halász, G. - Horváth, L. (2017): Innováció az oktatásban: az Innova kutatás elméleti-fogalmi keretei. Neveléstudomány, 4. évf., 26-43. https:// doi.org/10.21549/NTNY.20.2017.4.2

Grossman, P. L. (1995): Teachers' knowledge. In: Anderson, L. W. (szerk.): International encyclopedia of teaching and teacher education. Elsevier Science Ltd., Oxford.

Horváth, L. - Kovács, A. - Simon, T. - Zentai, A. (2015): Módszertani útmutató a pedagógusok folyamatos szakmai fejlódéséhez hozzájáruló tanuló szakmai közösségek, szakmai tanulócsoportok létrehozásának és müködtetésének támogatására. Oktatáskutató és Fejlesztő Intézet, Budapest.

Meirink, J. - Meijer, P. C. - Verloop, N. - Bergen, T. C. M. (2009): How do teachers learn in the workplace. An examination of teacher learning activities. European fournal of Teacher Education, 3. évf., 209-224.

Nagy-Rádli, D. (2018): Innovációs folyamatok a magyar oktatási rendszerben Összefoglaló gyorsjelentés az Innova kutatás első adatfelvételének eredményeiről. ELTE PPK, Kézirat. https://ppk.elte.hu/file/Gyorsjelent_s_2018.03.25__HG_.pdf

Nagy-Rádli, D. - Szarka-Bögös, R. (2019): Innovációs folyamatok a magyar oktatási rendszerben. Összefoglaló gyorsjelentés az Innova kutatás második adatfelvételének szervezeti és egyéni szintű eredményeiről. ELTE PPK, Kézirat. https://ppk.elte.hu/file/Innova_gyorsjelent_s_2_2019.02.pdf

OECD/Eurostat. (2018): Oslo Manual 2018. Guidelines for Collecting, Reporting and Using Data on Innovation (4th ed.). OECD/Eurostat, Paris/Luxembourg. 
Saqipi, B. - Rexhaj, X. (2012): Challenges and opportunities of school-based professional development in a decentralizing system. In: Education for the knowledge society 1st Albania International Conference on Education (AICE).

Schnellbach, M. (2014): Integrációs célú átfogó intézményfejlesztés egy budapesti általános iskolában. Neveléstudomány, 2014/4. sz.

Shulman, L. S. (1987): Knowledge and teaching: Foundations of the new reform. Harvard Educational Review, 57. évf., 1-22.

Tsui, Amy B. M. - Law Doris Y.K. (2007): Learning as boundary-crossing in school-university partnership. Teaching and Teacher Education, 23. évf., 12891301.

Vass, V. (2009): Implementations of key competencies and school improvement. In: Baráth, T. és Szabó, M. (szerk.): Does Leadership Matter? Implications for Leadership Development and the School as a Learning Organization. Nemzeti Tankönyvkiadó, Szeged. 117-129.

Vermunt, J. D. - Endedijk, M. D. (2011): Patterns in teacher learning in different phases of the professional career. Learning and Individual Differences, 21. évf., 294-302.

\section{Innovative work behaviour of teachers as a source of continuous professional development}

The purpose of this study is to draw relevant conclusions for the professional development of teachers from the secondary analysis of the research on local educational innovations. As a background knowledge for the secondary analysis, we have chosen the theoretical approach of workplace learning for teachers that combines innovative workplace behaviour of teachers with the topic of teacher learning. Our secondary analysis shows that the inspirational practice of other colleagues or institutions, the need to participate in different professional networks, or the need to solve a specific work/professional problem are important sources for the emergence and diffusion of innovations. In this context, research has reinforced the importance of employees' openness to innovation as an attitude that contributes to the emergence and diffusion of local innovations and learning processes related to that.

Keywords: continuous professional development, innovation, innovative work behaviour, Innova 